Article

\title{
Renewables, Preferential Trade Agreements and EU Energy Security
}

\section{Rafael Leal-Arcas *, Valentina Caruso and Raphaela Leupuscek}

The Centre for Commercial Law Studies, Queen Mary University of London, Mile End Road, London E1 4NS, UK; E-Mail: valentina.caruso@gmail.com; rleupuscek@hotmail.com

* Author to whom correspondence should be addressed; E-Mail: r.leal-arcas@qmul.ac.uk; Tel.: +44-20-7882-8071.

Academic Editor: Sonia E. Rolland

Received: 19 May 2015 / Accepted: 22 July 2015 / Published: 7 August 2015

\begin{abstract}
A major aim of the international community is to decarbonize the economy. With renewables, international trade in energy is likely to increase. In turn, the international trading system can be a major vehicle towards moving away from fossil fuels to renewable energy. To this end, it can provide fair competition, economies of scale and knowledge transfer. This article analyzes the impact of European Union (EU) preferential trade agreements (PTAs) in addressing climate change mitigation and energy security by promoting renewables. Currently, there is a proliferation of PTAs; this trend seems irreversible and is likely to persist, given the current crisis in the multilateral trading system. We argue that the EU can, through its network of PTAs, move towards greater energy independence as renewable energy becomes increasingly economically viable. This article provides a thorough review of the renewable energy-related provisions in the EU's current PTAs and recommends three tangible ways through which the EU could capitalize its vast network of PTAs to boost the renewable energy market.
\end{abstract}

Keywords: renewable energy; preferential trade agreements; energy security; EU; Energy Community; climate change 


\section{Introduction}

The purpose of this paper is both to analyze whether the European Union's (EU) preferential trade agreements (PTAs) include provisions aimed at promoting renewable energy and explore the potential of incorporating renewables-related chapters in the EU PTAs to boost the renewable energy market across Europe (and beyond) and reduce EU energy dependence. The paper considers renewables and trade in relation to the current environmental and economic climate. The natural gas pipelines between Russia and the EU were stopped in 2014 due to political tensions between Russia and Ukraine [1]. This shutdown is not ideal, as the majority of countries in the EU relies on Russia's natural gas imports to heat their homes [1]. It is, however, a good opportunity for the EU to seek and realize other trading opportunities in order to avoid situations like this one in the future. The paper also reflects on the importance for different countries as well as regional bodies to incorporate renewable energy in PTAs, as a good or a service that can be traded. Further, it considers what the most cost-effective renewable energies are and how they might be traded between States.

The paper is divided into four sections. After the introduction, Section 2 explores the link between EU energy security and renewables and analyzes the potential of the Renewables Directive to reduce EU energy dependency. Section 3 explains why the EU should opt for the promotion of renewable energy, inter alia, through its vast network of PTAs and the benefits the EU could achieve by capitalizing on its PTAs so as to encourage renewables. It evaluates 37 EU PTAs currently in force and notified to the World Trade Organization (WTO) to assess whether they encompass provisions aimed at fostering renewables. It suggests three tangible ways through which EU PTAs could be used to encourage the renewable energy market and make the EU increasingly energy secure. It considers whether the EU is able to facilitate the trade in renewable energy goods and services through PTAs. It is hoped that any capitalization made by the EU to use PTAs to encourage the trading of renewable energies will result in the EU becoming energy-independent. Section 4 concludes the paper.

\section{The EU Energy Security Strategy and Renewable Energy}

\subsection{Why Is Renewable Energy so Important?}

The EU has acknowledged how relevant renewables are to tackle the growing concerns about climate change and energy security. Indeed, the EU energy strategy is primarily aimed at increasing the use of renewable energy across the region, together with boosting energy efficiency ([2], p. 6). ${ }^{1}$ Since the EU is deeply dependent on energy from abroad, importing over $50 \%$ of all its energy [3], ${ }^{2}$ the promotion of renewable energy plays a leading role in reducing EU energy dependence and, at the same time, transforming "Europe into a highly energy-efficient and low greenhouse-gas-emitting economy" ([4], Preamble (4)), as well as achieving the binding mitigation targets for 2020 and the proposed reduction objectives for 2030 and 2050, envisaged by the EU climate agenda ([4], Article 3(1), Annex II; [5], para. $2.1 ;[6]$, para. 2).

1 The evaluation of EU law and policy on energy efficiency is outside the scope of the present paper. For a complete list of EU legislation concerning energy efficiency, see [2].

2 EU energy import dependency is particularly high for crude oil (more than 90\%) and natural gas (66\%), making the EU spending more than $€ 1$ billion per day to import the energy it needs. See [3]. 
The synergy and close interrelation between EU policies on climate change, renewable energy and energy security has been widely recognized in the 2009 Renewable Energy Directive (RED) [7], where the development of renewable energy is considered, along with fostering energy efficiency, the most effective tool 'in order to reduce greenhouse gas emissions within the Community' and to curtail 'its dependence on energy imports' ([7], Preamble (5)). Links between energy and environment have also been acknowledged in the European Energy Security Strategy (EESS) [8], where the European Commission has notably concluded that "energy security is inseparable from the 2030 framework for climate and energy and should be agreed together by the European Council" as the "transition to a competitive, low-carbon economy will reduce the use of imported fossil fuels by moderating energy demand and exploiting renewable and other indigenous sources of energy" ([8], p. 19).

The EESS emphasizes the need to exploit renewable sources of energy to mitigate climate change and to moderate energy dependence, and it points out decisions and concrete actions that would make the EU more energy secure. One of the fundamental objectives of the EESS is to boost overall EU energy production which, in the period 2000-2012, fell by almost 15\% ([9], p. 35), in spite of an increase of EU renewable energy primary production by more than $77 \%$ between 2001 and 2012 [10]. In this context, the EESS acknowledges that only by expediting the indigenous production of renewable energy, followed by the development of nuclear energy and the sustainable production of competitive fossil fuels (e.g., carbon capture and storage technologies for the sustainable use of coal), would it be feasible to slow the decline of EU total energy production ([8], p. 12; [11]). ${ }^{3}$ While recognizing the various benefits that would result from raising the production of renewable energy in Europe, including avoiding imported fuel costs amounting to at least EUR 30 billion a year and displacement of a significant volume of imported natural gas by furthering the use of renewable heating, the European Commission has also highlighted the barriers that stand in the way of an effective development of renewable energy across Europe. These barriers cripple the functioning of the renewable energy market and the confidence and fair competition required from private investors ([8], pp. 12-13). Among these obstacles are the following:

- Non-competitive costs of renewable energy technologies, although it is noted that "many renewable energy sources are increasingly competitive and ready to join the market (e.g., onshore wind power)" ([8], p. 12), ${ }^{4}$

- Lack of the required 'smarter energy grids and new energy storage solutions' in order to integrate renewable energy large-scale projects ([8], p. 12); and

- The need to adopt regional guidelines on public intervention (e.g., support schemes) to ensure that it is properly designed at the national level, thus, avoiding the risk that, whether not

3 It should be highlighted that, among oil, gas and coal proved reserves, the EU has considerable reserves only of coal (6.3\% of world proved reserved in 2013$)$, whereas those of oil $(0.4 \%)$ and natural gas $(0.8 \%)$ represented only a very small share of the global proved reserves in 2013. Therefore, regarding hydrocarbons, the EU could appreciably exploit only its coal reserves. See [11].

4 The International Renewable Energy Agency (IRENA) has published an important report on renewable power generation costs, which shows that renewable energy costs are continuing to fall, making renewable energy competitive with fossil fuels, the cheapest way to generate electricity in a growing number of markets (e.g., renewable energy in isolated and rural areas, and hydropower and geothermal at appropriate sites), and the most economical solution for new grid-connected capacity. See ([12], pp. 12-20). See also ([13], pp. 8-10). However, as of early 2015, the price of oil had decreased so drastically that renewables were not considered to be so attractive as a source of generating electricity. 
appropriately planned, it could be counterproductive, by distorting competition, investments and the functioning of the market ([8], pp. 12-13).

Even though the EU is actively promoting an increased use of renewable energy across Europe and beyond so as to reduce both its impact on climate change and its energy dependence, without having yet adopted the envisaged binding targets for 2030, the above-mentioned obstacles are still hindering the creation of a proper functioning and competitive renewable energy market, capable of attracting private investors' confidence and encouraging the market. Not least is the failure to price and internalize the costs of both climate-related and other externalities of fossil fuels (e.g., the costs of health damages) and the continuing subsidies to the fossil fuel industry ([13], pp. 16-17), amounting to \$550 billion in 2013 (more than four-times those of renewable energy) [14]. Such subsidies significantly decrease the capability of renewables to become competitive with fossil fuels and create barriers to the renewable energy market and investments. That said, the prognosis of renewable energy seems pretty bright if countries' climate change mitigation pledges are kept [15]. According to the International Energy Agency, renewable energy could become the top source of electricity by 2030 (see Figure 1) ([16], p. 12).

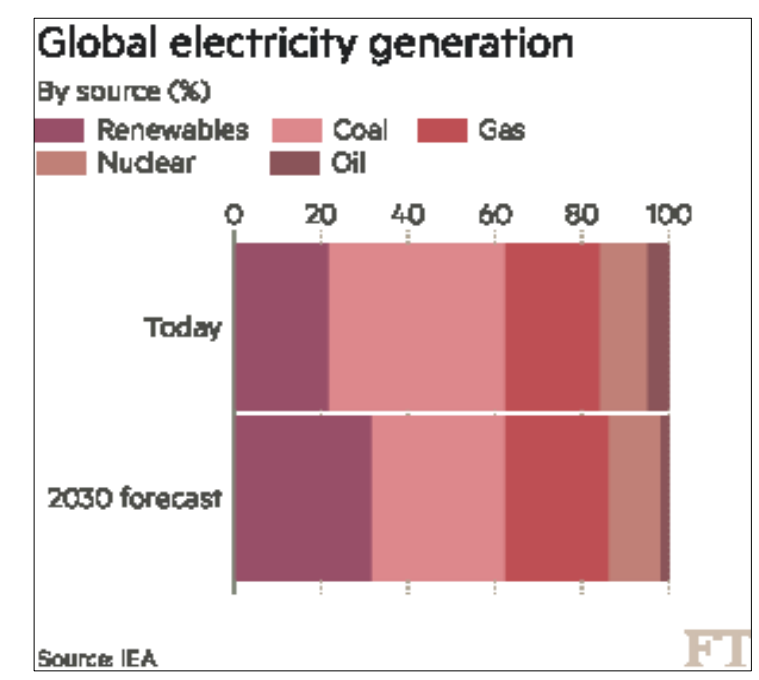

Figure 1. Global electricity generation.

\subsection{The Renewables Directive}

\subsubsection{Encouraging Trade in Renewable Energy Goods and Services}

It has been the goal of the European Commission for many years now to encourage the use of renewable energy within the EU ([17], pp. 24, 26-27). However, what seems to be the case is that this is being done in an internal way (between EU Member States), rather than reaching out to conclude renewable-energy-related agreements with other countries and regions. Some examples of EU legal instruments related to renewable energy include:

(1) The repealed Directive 2001/77/EC [18], which promotes electricity produced from renewable energy sources and sets an indicative target of 22 per cent for 2010 in the EU internal electricity market, as indicated in Article 3(4) of the Directive; 
(2) Directive 98/70/EC [19], which relates to the quality of petrol and diesel fuels and sets a mandatory target of 6 per cent reduction in GHG emissions and intensity of fuels used in road transport and non-road mobile machinery, as set out in recital 9 of the Directive; and

(3) Directive 2009/28/EC [7], which promotes the use of energy from renewable energy sources.

The Renewable Energy Directive (RED) enforced an objective for the quantity of renewable energy to be used in the EU. The goal amount was to be 20 per cent of the final energy consumption and this target was agreed to be met by 2020 ([7], Recitals 8, 9, 13, 15, 17 and 96, Article 3(1)). This was done for several reasons: to boost confidence in the industry, for there to be focus on a set policy objective, and to reduce any risks associated with long-term investments ([7], Recital 14, Article 3). Individual targets are allocated to each EU Member State and are calculated by reference to their GDP as well as their 2005 proportion of renewable energy, as this is the latest year for which there are reliable data on national shares of renewables ([7], Recitals 15, 21). Sweden had the highest target of 49 per cent, up from 39.8 per cent in 2005 ([7], Annex I at 46), and Malta had the lowest, at 10 per cent up from zero in 2005 ([7], Annex I at 46). If EU Member States do not fulfil their assigned objective, they are subject to enforcement action by the European Commission for failure to comply.

There are downsides, however, to such long-term targets. The shortcomings are that they postpone official judgment, compliance and sentencing to the target date, in the case of Directive 2009/28/EC and the 20-20-20 by 2020 policy it sets out ([20], p. 147). Until now, however, EU Member States do not have free reign [21] and are scrutinized for any decisions that may "seriously compromise the attainment of the result set out in the 2009/28/EC directive" ([20], p. 148). In order for Member States to show progress, they are required to submit a National Renewable Energy Action Plan (NREAP) that must set out that the state has or is going to take 'adequate measures' to achieve its national goal ([20], p. 148; [7], Article 4).

Some scholars argue what is essential for the transition to a green economy is continuous debate and scrutiny of the topic ([22], p. 2). One such influence is the Rio+20 conference, ${ }^{5}$ which provides for specific networks to support future discussions on trade as well as green economy by producing more knowledge, experience-sharing and informed discussions between countries and regional bodies ([22], p. 2). In particular, it sets out the fact that it is essential that the apprehensions of developing countries are addressed in these processes. One proposal is to establish an international knowledge-sharing platform that all countries can access to facilitate green policy formation and implementation ([22], p. 2). Finally, there is a suggested Sustainable Energy Trade Agreement initiative that could contribute by speeding up the 'development and adoption of renewable energy and clean technology globally' ([22], p. 2).

The effort by the EU to promote renewable sources through Directives is a positive step in the right direction. This is further heightened by the fact that trade in renewable energy goods and services can transpire between both EU Member States as well as third parties. This is set out in Article 1 of the 2009/28/EC Directive, which states that the Directive "lays down rules relating to statistical transfers between Member States, joint projects between Member States and with third countries..."

\footnotetext{
5 “'Rio+20' is the short name for the United Nations Conference on Sustainable Development which took place in Rio de Janeiro, Brazil in June 2012 — twenty years after the landmark 1992 Earth Summit in Rio”. See [23].
} 


\subsubsection{Potential for Energy Independence}

The RED establishes a common framework aimed at promoting renewable energy across Europe and envisages, inter alia, the following provisions:

(1) Mandatory national targets to be achieved in 2020 by each EU Member State, both for the share of energy from renewable sources in gross final consumption so as to enable the EU to get $20 \%$ of its overall energy consumption from renewable energy by $2020,{ }^{6}$ and for the share of energy from renewable sources in all forms of transport (i.e., at least $10 \%$ of the final consumption of energy in transport in each EU Member State) ([7], Article 3, Annex I);

(2) Support schemes to help EU Member States reach their targets - e.g., any instrument applied by an EU Member State or a group of EU Member States that encourages the use of renewable energy by reducing the cost of that energy, raising the price at which it can be sold, or intensifying the volume of the energy purchased, including investment aid, tax exemptions or reductions, tax refunds, feed-in tariffs and premium payments ([7], Articles 2(k), 3(3)(a));

(3) Information on support schemes to be made available to all relevant actors-e.g., "consumers, builders, installers, architects, and suppliers of heating, cooling and electricity equipment and systems and of vehicles" compatible with the use of renewable energy ([7], Article 14(1));

(4) Three cost-effective and cooperation mechanisms, resembling the flexible mechanisms provided in the Kyoto Protocol, that can be used by EU Member States, ${ }^{7}$ where the prescribed requirements are met, to achieve their renewable energy objectives more easily and profitably:

a. statistical transfers between EU Member States, under which Member States may transfer a certain amount of renewable energy from one Member State to another ([7], Article 6);

b. joint projects between Member States and between Member States and third countries so as to cooperate, also by providing access to private operators ([7], Articles 7(1), 9(1)), on all types of joint projects relating to the production of electricity, heating or cooling from renewable energy ([7], Articles 7, 9); and

c. joint support schemes, by which two or more EU Member States may decide to join or partly coordinate their national support schemes ([7], Article 11);

(5) National renewable energy action plans (NREAPs) to be adopted by each EU Member State in order to specify their renewable energy national targets and the appropriate measures to be taken to achieve such binding objectives and to fully implement the RED (e.g., planned statistical transfers, joint projects and national support schemes) ([7], Article 4);

(6) Any national rules concerning the authorization, certification and licensing procedures that are applied to renewable energy plants and related transmission and distribution networks have to be objective, non-discriminatory, proportionate, necessary and transparent, and must provide for clearly coordinated, defined, streamlined and expedited procedures, with transparent timetables for determining planning and building operations ([7], Article 13(1));

6 As the share of renewable energy in EU gross final energy consumption has increased from $8.3 \%$ in 2004 to $14.1 \%$ in 2012, the EU seems to be on track to meet its $20 \%$ target by the end of 2020. See [24].

7 Five EU Member States have forecast that they would need transfers of renewable energy from other Member States or third countries through the use of the cooperation mechanisms so as to reach their binding targets. See [25]. 
(7) Adequate actions have to be taken by EU Member States to develop 'transmission and distribution grid infrastructure, intelligent networks, storage facilities and the electricity system' ([7], Article 16(1)), along with interconnections between both Member States and Member States and third countries, to guarantee the secure operation of the system and its proper adaptation to the increasing employment of electricity from renewable energy;

(8) Burdensome obligations for transmission system operators and distribution system operators, including:

a. ensuring "either priority access or guaranteed access to the grid-system of electricity" produced from renewables ([7], Article 16(2)(b));

b. setting up and making public their standard rules regarding the 'bearing and sharing of costs of technical adaptations, such as grid connections and reinforcements,' which are necessary to integrate new renewable energy producers in the grid ([7], Article 16(3));

c. bearing, in full or in part, the costs of technical adaptations, whether EU Member States require them to do so ([7], Article 16(4));

d. providing any renewable energy producer wishing to have access to the system with the relevant information required ([7], Article 16(5)); and

e. charging transmission and distribution tariffs, which shall reflect realizable cost benefits resulting from the renewable energy plant's connection to the grid and shall not discriminate against gas from renewables ([7], Article 16(7)-(8)).

By setting up a common legal framework for renewable energy and providing for, inter alia, the above-mentioned provisions, the EU should be able to both promote an increasing use of renewable energy across Europe and move towards greater energy independence. First, promoting renewable energy in the EU means that the following outcomes should be reached in Europe, but also beyond its borders:

- $\quad$ Reducing GHG emissions by mitigating the impact of EU energy needs on the climate;

- Growth of renewable energy-related demand, market and investments through all the aforesaid measures (e.g., binding targets, support schemes and the legal stability and certainty provided by NREAPs), which represent the basic requirements to increase the competitiveness of the market and the confidence of economic operators in the system; and

- Making renewable energy increasingly economically viable, thanks to the growth of renewable energy-related demand, market and investments, which should stimulate research, development and innovation regarding more efficient, cost-effective and competitive renewable energy technologies.

Second, the RED is fostering greater energy independence in Europe, as it especially encourages the achievement of two of the eight EESS fundamental objectives: diversifying external supplies and related infrastructures; and increasing EU energy production. ${ }^{8}$

8 The eight pillars of the EESS are: immediate actions aimed at increasing the EU's capacity to overcome a major disruption during the winter 2014/2015; strengthening emergency/solidarity mechanisms including coordination of risk assessments and contingency plans; and protecting strategic infrastructure; moderating energy demand; building a well-functioning and fully integrated internal market; increasing energy production in the EU; further developing energy technologies; 
Whereas the Directive facilitates the diversification of energy supplies from abroad and their transmission systems, principally through the provisions on joint projects between EU Member States and third countries and on the appropriate actions to be taken by Member States to develop transmission infrastructures between Member States and third countries ([7], Articles 9-10, 16(1)), it also supports the growth of energy production in the EU by introducing national mandatory targets. ${ }^{9}$ Interestingly, EU primary production of renewable energy has indeed increased by almost $29 \%$ between 2008 and 2012 , compared with a lesser increase of approximately 24\% in the period 2004-2008 (i.e., before the adoption of the binding targets) [28], while EU overall energy production (renewable energy production included) has declined by almost 15\% in the period 2000-2012 ([9], p. 35).

However, the European Commission has pointed out various reasons for concern about the effective enforcement of the RED and, thus, on its future progress and achievements, some of which undermine private investors' confidence and the proper functioning of the renewable energy market ([29], pp. 12-14). Among these problems are:

(1) the slow implementation of the Directive, which hinders the promotion of renewable energy and the move towards greater energy independence and has forced the European Commission to start infringement procedures against different EU Member States; ${ }^{10}$

(2) Member States' deviations from their own NREAPs and changes to their national support schemes, which reduce the legal clarity and stability needed by private investors and increase their exposure to regulatory risks;

(3) administrative burdens and delays that still cause barriers and problems to the uptake of renewable energy, raising risks for renewable energy projects and investments; and

(4) slow infrastructure and transmission developments, delays in connection, and grid operational rules that disadvantage renewable energy producers and lessen the encouragement of true and fair competition.

Moreover, the main purpose of a framework that includes renewable energy mandatory targets is to provide the business community with the long-term stability and legal predictability it needs to make confident and rational investments in the renewable energy sector, which will, in turn, boost the use of renewable energy and its related market, make renewable energy more economically viable, mitigate climate change, reduce energy dependence and encourage an ongoing development of renewable energy technologies. Therefore, the EU institutions should act as soon as possible to complete the necessary

diversifying external supplies and related infrastructure; and improving coordination of national energy policies and speaking with one voice in external energy policy. See ([8], p. 3).

9 National targets refer to gross final consumption, and not to domestic production, for two main reasons: to help Member States reach their targets more easily, by making improvements in energy efficiency and thus lowering their energy consumption; and to allow Member States to use cooperation mechanisms so as to achieve their targets in a more cost-effective way, by counting within their targets an amount of renewable energy produced in other Member States or third countries. But, even though national targets refer to final consumption, since both energy savings with regard to final energy consumption have declined by approximately $6 \%$ in the period 2008-2012, and almost no cooperation mechanisms have occurred, Member States are primarily fostering a growth of national production of renewable energy. See ([26]; [27], p. 3).

10 Cases are open and Reasoned Opinions have been sent to Austria, Bulgaria, Cyprus, Czech Republic, Finland, Hungary, Ireland, Latvia, Luxembourg, the Netherlands, Poland and Slovenia. See ([29], p. 13). 
legislative procedure to make the proposed renewable energy objective for the period up to 2030 (i.e., 27\% of renewable energy share in the EU's gross final consumption) a binding national target ([5], para. 2.2) now that the European Council has finally agreed on it ([30], para. I(3)). ${ }^{11}$ This view is shared by a group of $61 \mathrm{EU}$ companies and associations that, in September 2013, issued a letter to the EU institutions calling for renewable energy binding national targets for the period 2020-2030. The letter states:

Given the long investment cycles in the energy sector and the fact that investment decisions in the EU's liberalised energy markets strongly depend on reliability, certainty about the regulatory framework of the next 17 years is needed. Such a framework bears the opportunity to reduce the current costs of uncertainty, mobilise the needed funding, help to protect the environment, decrease the costs of decarbonisation, facilitate the creation of new jobs and enhance the EU's technology leadership [32].

Therefore, only once all EU Member States have rigorously and comprehensively implemented the RED, its provisions being enforced without making deviations that can frustrate the market, and the proposed targets up to 2030 have become binding, can the EU "expect the renewable energy industry to be a thriving, mature and globally competitive one in the lead up to 2020 and beyond" ([29], p. 14). Moreover, only then could the EU finally be able to effectively promote renewable energy across Europe and outside its borders and to move towards greater energy security.

\subsubsection{Trading with Third Parties}

Trading with third parties will potentially allow the EU economy to develop at a greater pace and perhaps move towards becoming a green economy. The consent, however, of the EU entering into an agreement with a third country does have its limitations, as doing so is surrounded by measures that have to be complied with. These measures require positive action to be taken by both parties. One such example is Article 18(4) of the 2009/28/EC Directive, by which EU Member States ought to consider whether the third country they wish to enter into an agreement with is suitable. Article 18(4) sets out that, in order for any initial agreement to be made between the parties, the third country will have to have a set of criteria with regard to sustainable energy that complies with those of Directive 2009/28/EC. This ensures that the third state has the same obligations to comply with and safeguards all EU Member States from any damage that could otherwise emerge from the agreement.

Obligations on the EU Member State are set out throughout the other recitals, for example in 38, 39 and 74 of the 2009/28/EC Directive. These three points have requirements that need to be satisfied in order for the Member State to be able to engage with any third country and proceed with a trade agreement. Some of the restrictions include that EU Member States can only undertake projects with third countries where there are 'newly constructed installations or [...] installations with newly increased capacity' ([7], Recital 38) for the production of renewable energies.

Another matter is the production of biofuels and bio liquids, where the concern is that third countries might have different standards when manufacturing them ([7], Recitals 69-73). This could result in minimum environmental as well as social requirements not being met by the third country. This would create a problem because, by not meeting the minimum standards, the use and production of renewables

11 The next step for the European Commission for the post-2020 period is to adopt a legislative proposal. See ([31], p. 16). 
may be reduced. Fundamentally, these restrictions are in place so that the EU is protected, making the most out of possible agreements, benefiting the EU and its economy, rather than taking away from possible work and sources that can be provided from within the EU. The third countries' interests are also taken into consideration. Recital 38 of the 2009/28/EC Directive setting out that these requirements to engage only when there are newly constructed installations is done in order to "help ensure that the proportion of energy from renewable sources in the third country's total energy consumption is not reduced due to the importation of energy from renewable sources into the Community" ([7], Recital 38).

The support for trade agreements for renewables is also set out in the Energy Charter Treaty (ECT) [33] which, despite suffering a blow after Russia specified that it would not ratify it and withdrew from the treaty on 18 October 2009, is still firmly established and is the EU's chief international instrument in the area of energy ([34], p. 232). From the moment the ECT was considered, endorsed and launched, it was supported by the EU, thereby expressing the EU's interest in "safe energy supplies, stable political relationships, and trade and investment along its borders" ([34], p. 232). The content of the ECT is influenced by several factors, including investment treaty practice and EU energy policy trends at the time it was being established. Notwithstanding these elements, there are inherent problems that relate to the non-ratification by Russia. As a result, the nature of the ECT is changing and being questioned, the concern being the close proximity of the EU to the ECT ([34], p. 233).

Bamberger and Wälde wonder to what extent the ECT "can become a self-sustaining international arrangement able to survive independent of the EU" [35]. They argue that there is a public perception that the ECT is a key instrument of EU energy policy targeted at the East, often being mistakenly called the "European Energy Charter Treaty". When put in context, this does seem to be a pressing issue that needs to be addressed. Bamberger and Wälde's questioning of the proximity is necessary because, as a result of this proximity, there is confusion as to the aim of the ECT. One possible solution to this question could be the engagement of the EU with third countries. In doing so, it will establish the fact that the ECT is not intended to be an EU-specific treaty, but an international one embraced by countries worldwide [36].

\section{EU Preferential Trade Agreements and Renewable Energy}

PTAs are agreements whose aim is to aid in the trade of goods and services between countries by increasing and facilitating the ease with which commerce can be done. ${ }^{12}$ Conventionally, this allows the partner countries to give each other more favorable trade terms when compared with the terms placed on the countries that have been excluded from the agreement.

In its Green Paper 'A European Strategy for Sustainable, Competitive and Secure Energy' [38], the European Commission confirms that renewable energies will be the ones to tackle climate change, but also aid in the security of energy supplies ([38], p. 10). It is established that Europe is a continent that is abundant in renewable energy sources - including abundance in sun in the south, water in the north and wind along the coastlines ([38], p. 11). This is in contrast to conventional energy sources, which are regularly imported from regions that are politically insecure [39]. According to the European Commission, the EU in 2006 imported around 50\% of all its energy needs ([38], p. 3). At that time, they feared that this could increase to $70 \%$ by 2020 if no political countermeasures were taken ([38], p. 3).

12 For a definition of PTAs, see ([37], Article XXIV). 
What cannot be denied is that renewable energy is fundamental for the EU. This is because it can be transformed into 'electricity, heating/cooling and fuel' ([39], pp. 478-79) without having significant detrimental effects on the environment. However, due to the nature of renewable energy and the fact that it is a reasonably new source of energy, prices are still higher than conventional methods. This is why it is essential that renewables be incorporated in PTAs so that they can balance out any economic disadvantage that exists, while asserting themselves on the market and gradually being able to replace conventional energy sources ([39], pp. 478-79).

\subsection{Why Use PTAs to Promote Renewables?}

Even though the EU is actively promoting renewable energy across Europe to mitigate its impact on the climate and, at the same time, curtail its energy dependence without having yet adopted the envisaged binding targets for 2030, the European Commission has pointed out different obstacles that undermine the creation of a well-functioning and competitive renewable energy market, both with regard to the effective implementation of the RED by EU Member States and concerning the capacity to increase renewable energy production in the EU, such as the non-competitive costs of many renewables technologies and the lack of smart energy grids and energy storage solutions to enable their integration on a large-scale.

The approach proposed here to overcome these barriers is to promote renewable energy through the vast network of EU PTAs, ${ }^{13}$ so as to create a better trading environment for renewables. Indeed, "trade mechanisms can be an effective tool for securing environmental objectives" and "regional trade arrangements could be designed to provide for an attractive package to settle trade-offs and conflicts of interest" as well as facilitate an increased use of renewable energy ([42], p. 34).

Theoretically, the EU could also promote renewables through the adoption of a global trade agreement and/or an international climate change instrument, but such solutions seem rather unrealistic, given the stagnation of the multilateral trading system, the resulting proliferation of PTAs ([44], p. 367), and the stalemate of international climate change negotiations, which, in any case, would not require developing countries to undertake binding obligations. ${ }^{14}$ Moreover, a regional instrument may

13 In the WTO terminology, regional trade agreements (RTAs) are defined as reciprocal trade agreements between two or more partners and they include free trade agreements (FTAs) and customs unions (CUs). See ([37], Article XXIV (8)(a)-(b)). Preferential trade arrangements (PTAs) are defined as unilateral trade preferences and they include the Generalized System of Preferences (GSP) and other unilateral trade preferences. See [40]. Regarding all this international trade terminology, it is interesting to note that Jagdish Bhagwati prefers to use the term PTAs instead of RTAs "because the PTAs are not always regional in any meaningful sense. For example, the U.S.-Israel FTA is not regional. But the RTA terminology still persists at the WTO", see ([41], p. xi; [42], p. 34). For the purposes of this paper, the term EU PTAs is considered to encompass all reciprocal trade agreements between EU and one or more partners (e.g., RTAs, FTAs and CUs), but not the EU GSP and other unilateral trade preferences, which will not be assessed. Only EU PTAs notified to the WTO will be taken into consideration. For a list of all RTAs in force and notified to the WTO Secretariat, see [43].

14 The Doha COP18 amendment to the Kyoto Protocol, which provides for Annex I countries obligations to the Kyoto Protocol's second commitment period (2013-2020), is not yet a binding instrument since, as of 15 July 2015, only 38 Parties have deposited their instrument of acceptance and, among such 38 Parties, only three are Annex I Parties (i.e., Liechtenstein, Monaco and Norway). See [45]. In fact, in accordance with Articles 20(4) and 21(7) of the Kyoto Protocol, this amendment shall only enter into force once at least three fourths of the Parties to the Protocol (i.e., at least 128 of the 192 Parties) have deposited their instrument of acceptance. This means that, at present, while waiting for the so-called 
be more easily designed to take into consideration the different levels of development and capacities of each country, allowing for flexible approaches tailored to the needs and capabilities of specific partners. Such agreements also allow parties to pursue a distinct aim (e.g., economically-driven PTAs with developed countries and emerging economies, based on reciprocal market opening, and PTAs with LDCs which are mainly aimed at supporting development).

Thus, the suggested tool here to overcome the obstacles to a well-functioning and competitive renewable energy market is to promote renewables through the vast network of EU PTAs so as to establish and develop better trading opportunities. In fact, availing of EU PTAs to boost renewable energy would have, inter alia, the following outcomes: making the policy and legal environment more predictable; opening new markets; increasing investment opportunities; making trade faster by facilitating transit through customs and setting common rules; stimulating research and innovations on more efficient, cost-effective and competitive renewable energy technologies; and making renewable energy technologies cheaper by eliminating substantially all customs duties and boosting their market and investments ([46], p. 3).

Furthering trade in renewable energy goods and services and making them more economically viable and competitive would indeed help EU Member States implement and enforce the RED (for example, the business community would embrace a growing use of renewable energy and national support schemes would be less needed), and also help to overcome the barriers that still stand in the way of an effective development of renewable energy across Europe and undermine EU energy security (e.g., high costs). This, in turn, would significantly benefit the EU in reducing both its GHG emissions and energy dependence. Therefore, the question is how (i.e., through which provisions) the EU can use its network of PTAs to support the renewable energy market across Europe and beyond, thus achieving greater energy security and, at the same time, lowering its carbon impact, thereby addressing climate change.

\subsection{Renewable Energy-Related Provisions in EU Preferential Trade Agreements}

\subsubsection{Setting the Scene}

PTAs are reciprocal trade agreements between two or more partners which grant preferential and privileged access to each other's markets, favoring member parties over non-members by extending tariff and other non-tariff preferences. Thus, PTAs are, by their very nature, discriminatory trade arrangements, departing from the WTO's first and fundamental principle of equal treatment and non-discrimination ([37], Article I; [47], Article II; [48]). WTO Members are, however, permitted to enter into such agreements under specific rules and conditions (e.g., PTAs must liberalize 'substantially all trade' between partners) ([37], Article XXIV (4)-(10); [47], Article V), and are also required to notify their PTAs to the WTO ([37], Article XXIV (7); [47], Article V (7)). The increasing number of PTAs has the potential to be instrumental for the multilateral trading system, complementing and strengthening it (e.g., by multilateralizing and integrating PTAs in the WTO) and helping countries to coordinate their positions and policies before moving towards the multilateral forum.

2015 Climate Change Agreement (to be adopted in the COP21 in Paris in 2015 and to be implemented from 2020), there are no binding emission reduction targets in force at the international level. 
Conversely, the proliferation of PTAs is also seen as a threat to the WTO system, causing regulatory fragmentation, confusion and uncertainty, as well as legal conflict, lack of coordination and coherence, unfair trade relations, and also exponential increase in business costs [49]. And even though there is now an institutional acceptance that PTAs should be considered a serious concern for the multilateral trading system [49,50], PTAs have proliferated worldwide and the EU, which is a PTA itself, has developed a vast network of PTAs. ${ }^{15}$ Moreover, PTAs are not regarded as a risk for the WTO system solely because of their proliferation, but also because their scope is increasingly broadening. Indeed, PTAs are no longer just about trade, and new preferential agreements, especially those signed by the EU and the United States (US), no longer only contain provisions covered by the WTO agreements (i.e., trade in goods and services and trade-related aspects of intellectual property rights), but also regulate areas currently lying outside the WTO mandate (e.g., competition, labor standards, investment and environmental protection) ([50], pp. 157-65; [52]).

Regarding the content of the EU's PTAs, it is essential to mention the main findings of an eminent study [50] conducted by three researchers affiliated with the Bruegel Institute (hereinafter, the Bruegel study), that analyzed and compared the precise content of 14 US and 14 EU PTAs signed with WTO member countries and notified to the WTO as of October 2008 (thus excluding those where the partner is not a party of the multilateral trading system). ${ }^{16}$ The research divided all the provisions covered by US and EU PTAs into two categories: WTO plus (WTO+), consisting of 14 policy areas, and WTO extra (WTO-X), comprising 38 policy areas. Whereas the first group contains those provisions that fall within the mandate of the WTO, as partners undertake commitments going beyond those granted at the multilateral level (e.g., reduction in tariffs), the WTO-X category includes provisions regulating areas outside the WTO mandate (e.g., commitments on labor standards, energy and environmental protection). Moreover, to better assess the impact of EU and US PTAs, the Bruegel study underlines whether or not each PTA obligation is legally enforceable, thus determining which provisions provide for unclear and unspecified undertakings and which, conversely, may be successfully invoked in a dispute settlement procedure. The main findings of the Bruegel study are:

- Both EU and US PTAs encompass a significant number of legally enforceable commitments in WTO+ policy areas (e.g., all PTAs include binding obligations regarding tariff liberalization for industrial and agricultural products), however, even though the difference is not as marked as for the WTO-X obligations, fewer provisions included in EU agreements tend to be enforceable than those of the US;

- EU agreements contain almost four times the number of WTO-X provisions covered in US PTAs;

15 Regarding the global proliferation of PTAs, as of 7 April 2015, the WTO had received 612 notifications of RTAs, of which 406 are in force. See [51].

16 Regarding the PTAs scrutinized in the Bruegel study, it is underlined that EU PTAs with individual Member States of the European Free Trade Association (EFTA) (i.e., Iceland, Lichtenstein, Norway and Switzerland) and the European Economic Area (EEA) Agreement (between the EU and EFTA Member States, except Switzerland) count as one EU PTA; and that there are EU PTAs with the following partners: Member States of the EEA plus Switzerland, Turkey, Tunisia, Israel, Morocco, Jordan, South Africa, Mexico, The former Yugoslav Republic of Macedonia, Egypt, Croatia, Chile, Albania and CARIFORUM. See ([50], pp. 154-55). 
- EU agreements include far fewer legally enforceable WTO-X provisions than US PTAs, showing a considerable degree of legal inflation in WTO-X areas, a phenomenon that is significantly less for WTO+ obligations;

- All EU PTAs, except for the EU-Turkey Agreement, cover energy-related WTO-X provisions, but only one contains legally enforceable obligations regarding energy policy (i.e., the European Economic Area (EEA) Agreement), whereas all the other 12 EU PTAs contain no binding commitments on energy.

Although the Bruegel study sheds light on the content of EU PTAs, it does not focus on energy-related provisions included in EU agreements. Rather, it determines the legal nature of such commitments and whether they are encompassed within the PTAs. Furthermore, this study does not mention RE at all. Therefore, further research is needed to evaluate whether EU PTAs already include provisions aimed at the promotion of renewables.

Indeed, whereas the Bruegel study has notably scrutinized all the WTO+ and WTO-X obligations comprised in the 14 EU PTAs signed with WTO Member States and notified to the WTO as of October 2008, the present section aims at assessing only the WTO-X renewable energy-related provisions contained in the PTAs which the EU has concluded as of November 2014, both with WTO members and non-members.

The following sections will evaluate 37 EU PTAs in force to see whether they contain renewable energy-related provisions. We will analyze the following agreements:

1. The European Economic Area (EEA) Agreement and EU PTAs with the Member States of the European Free Trade Association (EFTA);

2. EU PTAs with contracting parties to the Energy Community (EnC) Treaty and Georgia;

3. EU PTAs with the Union for the Mediterranean (UfM) Member States;

4. EU-Andorra and EU-San Marino PTAs; and

5. EU PTAs with non-neighboring countries.

\subsubsection{The European Economic Area Agreement and EU PTAs with EFTA Member States}

In 1973, the European Community started concluding PTAs with EFTA Member States, following the first accessions of EFTA Members States to the European Community and, in 1992, negotiations with the remaining EFTA countries finally resulted in the creation of the EEA. ${ }^{17}$ Because of the close and long-running relations between the EU and the EFTA, the EEA Agreement and the EU PTAs with individual EFTA Member States ${ }^{18}$ will be analyzed together.

The EEA Agreement brings together the 28 EU Member States and three of the four EFTA Member States (i.e., Norway, Iceland and Liechtenstein, but not Switzerland) in the EU internal market by requiring the EEA-EFTA states the application of the relevant acquis communautaire [54]. ${ }^{19}$ The EEA Agreement is thus aimed at guaranteeing the free movement of persons, goods, services, and capital (i.e.,

17 The EEA is a free-trade area formed on the basis of an agreement between, on the one hand, all but one of the Members of the European Free Trade Association (EFTA) (namely Switzerland) and, on the other, the countries of the EU. The entire EU internal market acquis - save for that on fisheries and agriculture - applies to the EEA. See [53].

18 Currently, the EFTA Members are Iceland, Liechtenstein, Norway and Switzerland.

19 EU Member States are bound to comply with all the EU legal acts under the EU treaties. See ([55], Article 288). 
the four fundamental pillars of the EU internal market) among the EEA Member States so as to remove barriers to trade and encourage the economic growth and the international competitiveness of the entire EEA ([54], Article 1). Regarding the rules on the free movement of goods, Article 24 of the EEA Agreement establishes that Annex IV of the EEA Agreement [56] contains energy-related provisions, which include the RED. Since Liechtenstein has been exempted from applying Directive 2009/28/EC ([56], para. 41(a)), only Iceland and Norway are required to enforce the renewables acquis, but with some adaptations:

(1) their mandatory national targets are not included within the overall EU target of at least a $20 \%$ share of renewable energy in the EU final consumption of energy in 2020 ([7], Article 3(1)); and

(2) they have to notify their national renewable energy action plans (NREAPs) and report them to the EFTA Surveillance Authority (EFTA-SA), and not to the European Commission ([56], para. 41(b)-(c)).

As already in 2005 Iceland had a share of renewable energy in energy consumption of 55\% and Norway of $58.2 \%$ (shares higher than those recorded up to 2012 by any EU Member State), ${ }^{20}$ their targets for 2020 were set at $64 \%$ and $67.5 \%$, respectively ([56], para. 41(e)). Thanks to the cooperation between the EU and the EEA-EFTA states, the scope of application of the renewables acquis has thus been extended to Iceland and Norway, which own significant renewable energy sources and exploit a considerable amount of renewables in their energy consumption. Therefore, the EU's capability to boost renewable energy across Europe and to move towards greater energy independence has been furthered by enlarging the RED's scope of application to Iceland and Norway. Indeed, the legal framework provided by the RED could be an effective tool to create a well-functioning and competitive renewables market (by ensuring the business community the long-term stability and legal certainty they need to make rational investments in the renewable energy sector), make renewable energy increasingly economically viable, stimulate research and developments, and promote energy security. Undoubtedly, Norway and Iceland could be, for instance, key partners for EU Member States in the development of cooperation mechanisms (e.g., statistical transfers and joint projects) so as to enable EU Member States to reach their renewable energy binding targets in a more flexible and cost-effective way.

The success of the RED surely depends upon a uniform and effective implementation of the renewables acquis by all the EEA Member States. Whereas the European Commission monitors the implementation of EU legal acts by EU Member States, the compliance of the EEA-EFTA parties with EEA law is supervised by the EFTA-SA, which may also receive complaints from private individuals and economic operators alleging an infringement of the EEA acquis [58]. Moreover, a two-pillar structure has been envisaged for judicial procedures: while the Court of Justice of the EU (CJEU) has jurisdiction with regard to EU Member States ([55], Articles 258-60), the EFTA Court has jurisdiction over the EEA-EFTA countries. Significantly resembling the procedures of the CJEU, the EFTA Court has been entrusted with the mandate to decide infringement actions brought by the EFTA-SA against any EEA-EFTA party, to give advisory opinions to the national courts of the EEA-EFTA states, and to decide as a court of appeal with respect to the decisions taken by the EFTA-SA ([58], Article 36). To conclude with the analysis of the renewable energy-related provisions in the EEA Agreement, it is fair

20 In 2012, the EU Member States' highest share of renewable energy in energy consumption was held by Sweden (51\%), followed by Latvia (35.8\%) and Finland (34.3\%). See [57]. 
to say that the EEA legal and institutional system provides for legally binding and enforceable provisions aimed at promoting renewable energy, which are currently those enshrined in the RED.

Regarding the EU PTAs with individual EFTA Member States, the following can be said:

- Neither the EU-Iceland [59] nor the EU-Norway [60] PTA provide for any renewable energy-related provision, but Iceland and Norway are bound to implement the EU acquis on renewables under the EEA Agreement; and

- The EU-Switzerland/Liechtenstein PTA $[61,62]^{21}$ does not contain any renewable energy-related provision. Moreover, neither Switzerland nor Liechtenstein is required to apply the provisions of the RED, as Switzerland never signed the EEA Agreement and Liechtenstein has been exempted from implementing the Directive. ${ }^{22}$

\subsubsection{EU PTAs with the Energy Community’s Member States and Georgia}

A Note about the Energy Community

Since the goal of the EESS regarding energy policy with neighboring countries is 'to engage all partners at all levels in order to enable their close integration into the EU energy market' ([8], p. 18), the Energy Community (EnC) 'should be further strengthened in the light of the EU's security of supply concerns' ([8], p. 18). The EnC is an international organization based on the Treaty Establishing the Energy Community (EnCT) [64], signed in 2005 between the EU and the following eight Contracting Parties (CPs): Albania, Bosnia and Herzegovina, Kosovo, ${ }^{23}$ Macedonia, Moldova, Montenegro, Serbia, and Ukraine [67]. The EnC has been entrusted with the mandate of creating a "legal and economic framework in relation to Network Energy" ([64], Article 2(1)), which is defined in paragraph 2 of Article 2 EnCT as including 'the electricity and gas sectors falling within the scope of the European Community Directives 2003/54/EC and 2003/55/EC' [68,69]. Among the EnC fundamental objectives are:

(1) Organizing the cooperation between the CPs in order to create a stable regulatory and market framework for energy trade "capable of attracting investment in gas networks, power generation, and transmission and distribution networks" and of ensuring the access of all Parties to a "stable and continuous energy supply" ([64], Article 2(1)(a));

(2) Enhancing energy security 'by providing a stable investment climate in which connections to Caspian, North African and Middle East gas reserves can be developed, and indigenous sources of energy such as natural gas, coal and hydropower can be exploited' ([64], Article 2(1)(c)); and

21 The application of the Agreement between the European Economic Community and the Swiss Confederation is extended to Liechtenstein. See ([62], Article 1).

22 Since 2007, Switzerland has been negotiating with the EU a bilateral agreement in the electricity sector; however, no negotiation has been concluded to date concerning the transposition of the EU internal energy market acquis in the Swiss legal system. See [63].

23 The EnC clarifies that the status of Kosovo as an EnC Contacting Party is without prejudice to positions on its status as an independent state and is in line with the Opinion of the International Court of Justice, which ruled that the declaration of independence of Kosovo, adopted on 17 February 2008, does not violate international law. See [65,66]. 
(3) To 'improve the environmental situation in relation to Network Energy and related energy efficiency, foster the use of renewable energy, and set out the conditions for energy trade in the single regulatory space' ([64], Article 2(1)(d)).

Regarding the provisions aimed at establishing an internal energy market, the EnCT prohibits its Parties to levy any 'customs duties and quantitative restrictions on the import and export of Network Energy and all measures having equivalent effect' to one another ([64], Article 41(1)), with the exception of those measures which can be justified on grounds of public policy, public security, the protection of health and life of humans, animals and plants, or the protection of industrial and commercial property and, cumulatively, do not "constitute a means of arbitrary discrimination or a disguised restriction on trade between the Parties" ([64], Article 41(2)).

Moreover, in order to establish a common and stable regulatory and market framework for energy trade, Contracting Parties are committed to implementing key areas of the "acquis communautaire on energy, environment, competition and renewables" ([64], Article 3(a)), ${ }^{24}$ including EU legislation on electricity, oil and gas, security of supply, and promotion of energy efficiency and biofuels. By importing EU law in non-EU countries and requiring CPs to liberalize their energy markets in line with the acquis under the EnCT, the EnC has a threefold scope of ambition:

- National: in the short-term, it aims at "creating open and transparent national energy markets", capable of increasing legal certainty and, thereby, attracting investments in power generation and networks ([71], p. 2);

- Regional: in the medium-term, it pursues to build "an integrated energy market" across the EnC region, which allows a secure energy trade between the CPs, guarantees energy supply and takes into account climate, environmental and social concerns ([71], p. 2); and

- Pan-European: in the long-term, it is committed to fully assimilate the EnC regional market in the EU internal energy market ([71], p. 2).

Since the EnC acquis needs to be revised in line with the continuous evolution of relevant EU law, the EnC Ministerial Council is mandated to take the appropriate measures for amending EnC legislation ([64], Articles 24-25, 47). ${ }^{25}$ Hence, Article 20 of the EnCT on the acquis for renewables has been specifically amended so as to include the RED ([72], Article 1). Therefore, in addition to the EU Member States and the EEA-EFTA Member States, the eight EnC CPs are required to enforce the RED and to achieve by 2020 their own national renewable energy binding targets ([72], Article 4), but with the following ad-hoc adaptations:

1. They should have implemented the Directive by 1 January 2014 and not by 5 December 2010 ([72], Article 3(1)(i));

2. They are required to notify their NREAPs (by 30 June 2013 and not by 30 June 2010) and to report to the EnC Secretariat and not to the European Commission ([72], Articles 3(1)(d), $5(1), 15)$; and

3. They are allowed to participate in the cooperation mechanisms both among themselves and with EU Member States, but statistical transfers and joint support schemes between CPs and EU

24 For an updated list of the EU legislation that forms part of the EnC acquis, see [70].

25 The EnC Ministerial Council is the EnC executive organ and consists of one representative for each CP and two for the EU. 
Member States are subject to an independent and external audit to be established by the EnC country concerned ([72], Articles 8-9).

Therefore, thanks to the transposition of the Directive in the EnCT, the scope of application of the renewables acquis has thus been widened to the $\mathrm{EnC}$ region, which has a great growth potential in renewable energy production, especially in hydropower. ${ }^{26}$ Considering that the common legal framework provided by the RED could be an effective tool to create a competitive renewable energy market and to make renewables increasingly economically viable, to stimulate research and innovations on more efficient and cost-effective renewable energy technologies, and to improve energy security, the EU has increased its chances of boosting renewable energy and moving towards greater energy independence by extending the scope of application of the RED to the eight EnC CPs. Since the transposition of the renewables acquis in the EnC region depends upon a uniform and effective implementation of the Directive by all CPs and since the European Commission supervises the transposition of the EU legal acts by EU Member States, the EnC Secretariat has been entrusted with the mandate of monitoring the compliance of the EnC CPs with their obligations under the EnCT ([64], Article 67).

Furthermore, the EnCT envisages a dispute settlement mechanism that, resembling the EU infringement procedure, may be initiated by the Secretariat on its own initiative or in response to allegations submitted by either private persons (i.e., interested natural and legal persons, including companies, firms or associations having no legal personality), CPs or the Regulatory Board ([74], Title II). The Secretariat may also bring the case to the Ministerial Council, which has the power to take binding decisions establishing whether the Party concerned has violated the EnC acquis and, in cases of serious and persistent breaches, may also suspend some of the rights conferred by the EnCT ([64], Title VII; [74], Title III). Not surprisingly, the 2014 implementation report of the EnC Secretariat has pointed out the lack of a full and effective compliance with the RED provisions by the EnC parties, some of which cripple the development of private investors' confidence and the proper functioning of the renewable energy common market [73].

In fact, the Secretariat has acknowledged that most of the CPs will fail to fully comply with the provisions of the RED by 2020 as it was forced to open infringement procedures against the majority of them for not even submitting their NREAPs (only Kosovo, Moldova, and Serbia notified it) and has, furthermore, underlined the need to review the existing legal and regulatory framework in all state parties to properly transpose the Directive (e.g., provisions on cooperation mechanisms have not been transposed in any CP, whereas Kosovo has only implemented part of them) ([73], p. 13). Therefore, the creation of a common and competitive renewable energy market in the EnC is currently challenged by the lack of an appropriate implementation of the RED by the EnC CPs. Moreover, since the EnC was created for an extendible period of 10 years, expiring in July 2016 ([64], Article 97), the EnC Ministerial Council should decide as soon as possible extending the EnC expiry date beyond 2016 so as to provide the business community with the long-term stability and legal certainty they need to make confident and rational investments in the renewable energy sector.

Evaluation

26 Currently, hydropower is the most commonly used type of renewable energy in the eight non-EU EnC CPs. For instance, in Albania, hydropower accounts for $20 \%$ of the gross domestic consumption. See ([73], p. 20). 
Proceeding with the evaluation of the EU PTAs with individual EnC CPs, the following is highlighted:

- Kosovo is the only EnC Party who has not yet signed a PTA with the EU;

- $\quad$ EU PTAs with Albania [75], Bosnia and Herzegovina [76], Macedonia [77], and Montenegro [78] do not include any renewable energy-related provision;

- The EU-Albania PTA does not provide for any renewable energy-related provisions, but it contains one article on the cooperation in energy policy which provides for cooperation "on priority areas related to the Community acquis in the field of energy" that "shall be based on the signed regional Energy Community Treaty with a view to the gradual integration of Albania into Europe's energy markets" ([75], Article 107), thus recognizing the fundamental role of the EnC in the formulation of energy law and policies;

- EU PTAs with Moldova, Serbia and Ukraine do formulate renewable energy-related provisions; and

- Whether or not EU PTAs with EnCT parties include provisions designed at fostering renewables (even in the case of Kosovo, which has not signed any PTA with the EU), all the EnCT parties are required to implement the acquis on renewables under the EnCT, and the provisions of the RED may be legally enforceable through the EnC infringement procedures.

Having made these clarifications, renewable energy-related provisions in the EU PTAs with Moldova, Serbia, and Ukraine will now be assessed. In addition, since Georgia is in the process of accession to the EnC, an analysis of the renewable energy-related provisions in the EU-Georgia PTA is provided.

The EU-Moldova PTA encompasses an entire chapter on energy cooperation, in which it is established that such cooperation "shall cover", among others, "the development of competitive, transparent and non-discriminatory energy markets in accordance with EU standards, including obligations under the Energy Community Treaty", the "development and support of renewable energies in an economic and environmentally sound manner" and the "reduction of emissions of greenhouse gases, including through energy efficiency and renewable energy projects" ([79], Article 77(b), (f)-(g)). Renewables are also considered in the provision on trade and investment promoting sustainable development, where it is set forth that parties "shall strive to facilitate and promote trade and investment in environmental goods and services, including through addressing related non-tariff barriers", and to "facilitate the removal of obstacles to trade or investment concerning goods and services of particular relevance to climate change mitigation, such as sustainable renewable energy and energy efficient products and services", so as "to enhance the contribution of trade to the goal of sustainable development" ([79], Article 367(b)-(c)). However, sharing the same methodology used by the Bruegel Study to determine the extent to which provisions are legally enforceable and taking into account the terminology chosen for their formulation ([50], pp. 156-57), such commitments seem to be weak, general, unclearly specified, and non-enforceable undertakings. Therefore, even though these provisions indeed encourage a cooperation aimed at boosting renewables to mitigate climate change and achieve sustainable development, they cannot be regarded as legally enforceable commitments. However, the EU-Moldova PTA requires Moldova to carry out approximation of its legislation to the EU legal acts referred to in Annex VIII of the Agreement ([79], Article 79), which currently includes the RED. Thus, as the Directive has been incorporated in the PTA, Moldova must implement and enforce the provisions of the RED not only under the EnCT but as well under the PTA itself. 
The EU-Serbia PTA [80] comprises two provisions aimed at supporting renewables, however, without mentioning the implementation of the RED. The first provision is found in Article 109 on cooperation in the energy sector, where it is stated that such cooperation:

(1) "shall focus on priority areas related to the Community acquis in the field of energy";

(2) "It shall be based" on the EnCT;

(3) "it shall be developed with a view to the gradual integration of Serbia into Europe's energy markets"; and

(4) "may include", among others, "the promotion of energy saving, energy efficiency, renewable energy and studying the environmental impact of energy production and consumption" ([80], Article 109).

The second provision is to be found in Article 111 on cooperation in environmental policy, where it is recognized how such cooperation "could also centre on the development of strategies" pursuing the creation of a "framework for efficient, clean, sustainable and renewable production and consumption of energy" ([80], Article 111). Again, even though these two provisions boost a cooperation aimed at increasing the use of renewables, they seem to be weak, general, and non-enforceable commitments.

Similarly to the EU-Serbia Agreement, the EU-Ukraine PTA [81] does not mention the RED and provides for two non-enforceable provisions aimed at furthering renewable energy: the first relating to trade and sustainable development ([81], Article 293(2)), and the second to cooperation in energy policy ([81], Article 338(j)-(k)). In order to encourage trade favoring sustainable development, partners "shall strive to facilitate and promote trade and foreign direct investment in environmental goods, services and technologies", including "sustainable renewable-energy and energy-efficient products and services' by 'addressing related non-tariff barriers" ([81], Article 293(2)), thus boosting renewable energy-related trade and investments. As for cooperation in energy policy, mutual cooperation on energy matters shall cover, among others, the "development of and support for renewable energies in an economic and environmentally sound manner", and the "promotion of the Joint Implementation Mechanism under the Kyoto Protocol [...] to reduce emissions of greenhouse gases through energy efficiency and renewable energy projects" ([81], Article 338(j)-(k)). Even though the latter provision is particularly interesting, given that it mentions the key role of renewable energy projects under the framework of the flexible mechanisms envisaged by the Kyoto Protocol, it is currently of little use, as the first commitment period of the Kyoto Protocol has expired and the Doha amendment to the Kyoto Protocol regarding the second commitment period (2013-2020) is not yet in force.

The EU-Georgia PTA [82], signed in June 2014, fully reflects the status of Georgia as a candidate member to the EnC and the negotiations launched by the European Commission in February 2014 to enable Georgia to join the EnC [83]. With the purpose of advancing the integration process in the region, the government of Georgia officially applied for membership of the Energy Community, which serves as a basic platform for countries willing to join the European Union and its energy market. The Energy Community extends the EU's internal energy market to South East Europe. The signatories of the Energy Community Treaty agree to implement the acquis communautaire related to natural gas, electricity, competition, renewables, and energy efficiency, with the purpose of implementing the key priorities of the Treaty and creating a regional gas and electricity market within South East Europe. Energy Community membership and rules are advantageous because they enhance competition in the market and attract 
investments for a stable and continuous energy supply, creating an integrated energy market with the EU's common energy market, increasing the quality of security of supply, as well as improving the environmental situation.

The EU Agreement with Georgia is an Association Agreement used by the EU to bring countries of Eastern Europe closer to EU standards and norms. ${ }^{27}$ It offers enhanced cooperation in almost all policy areas, including political dialogue and cooperation in the field of foreign and security policy, a chapter on justice, freedom and security, a chapter on trade and trade-related matters, chapters on economic cooperation, financial assistance and anti-fraud provisions, as well as on institutional provisions. In addition, it contains an entire Annex on energy that provides a list of both EU legislation and international legal instruments that Georgia has undertaken to progressively transpose into its legal system within specified timeframes ([82], Annex XXV). Regarding the RED, Georgia is due to implement the provisions of the Directive in accordance with the timeline agreed by the EnC: where the accession of Georgia to the EnC Treaty should not become effective within two years of the entry into force of the PTA, a proposal for a new timeframe will be submitted to the Association Council no later than three years after the entry into force of the PTA ([82], Annex XXV) ${ }^{28}$ By becoming a full-fledged EnC Treaty Party and implementing the EU energy acquis, Georgia will thus have closer ties with the EU internal energy market, attracting investments and increasing the financial sustainability of the energy sector. By implementing the RED, Georgia would, moreover, contribute to boost the renewables-related market and investments.

Besides the provisions of the RED that will become enforceable only once Georgia will accede to the EnC, the EU-Georgia PTA encompasses two articles aimed at supporting renewable energy, one concerning trade and sustainable development and the other on the cooperation in energy policy. In order to enhance their contribution of trade and investment to sustainable development, Parties 'shall strive to facilitate the removal of obstacles to trade or investment concerning goods and services of particular relevance to climate change mitigation, such as sustainable renewable energy and energy efficient products and services' ([82], Article 231 (c)). Cooperation on energy issues 'should cover', among other areas, the 'development and support of renewable energies with a primary focus on hydro resources and promotion of bilateral and regional integration in this field' ([82], Article 298 (i)). However, these two provisions seem to be formulated so as to provide only for weak, general and non-enforceable commitments.

\subsubsection{EU PTAs with the Member States of the Union for the Mediterranean}

The Union for the Mediterranean (UfM) is a multilateral partnership created in 2008 in order to increase the potential for regional integration and cohesion among the $28 \mathrm{EU}$ Member States and the following 15 Mediterranean states: Albania, Algeria, Bosnia and Herzegovina, Egypt, Israel, Jordan, Lebanon, Mauritania, Monaco, Montenegro, Morocco, Palestine, Syria, ${ }^{29}$ Tunisia and Turkey [86]. Given

27 For further details on Association Agreements, see [84].

28 The Association Council has the mandate to supervise the implementation of the Agreement between the EU and Georgia. See ([82], Article 404(1)).

29 Syria has been suspended as a member of the UfM. Currently, all relations between the EU and the Syrian government are frozen. See [85]. 
that the EU has not yet signed a PTA with Mauritania or Monaco, ${ }^{30}$ and that the EU's trade agreements with Albania, Bosnia and Herzegovina, and Montenegro have already been evaluated in the context of the far-reaching energy cooperation established within the Energy Community, only the EU PTAs with the remaining 10 non-EU UfM Member States will be scrutinized in order to evaluate whether they include renewable energy-related provisions. But first, a word about the role of the UfM, and particularly of its Secretariat, in the promotion of renewables projects in the Mediterranean region.

The UfM and Renewables

As the "recent activity on energy markets in terms of both supply and demand, confirms the need to focus on alternative energy sources" and "market deployment as well as research and development of all alternative sources of energy" are considered a "major priority in efforts towards assuring sustainable development" ([86], p. 19), since its establishment, the UfM has stressed the importance of boosting the use and development of renewable energy in the Mediterranean region. In order to further encourage cooperation among its Member States on renewables projects, the UfM has envisaged the Mediterranean Solar Plan (MSP). The UfM Secretariat is the body entrusted with the mandate of identifying, elaborating, promoting, coordinating and following-up the UfM's regional projects, also by searching for funding and working as the institutional focal point for multi-source funding of projects ([89], Section II), and has been "tasked to explore the feasibility, development and creation of a Mediterranean Solar Plan" ([86], p.19). The MSP is, among others, designed to ([90], p. 1):

- Serve as a shared roadmap for the development of a common policy framework aimed at creating the appropriate legal, regulatory, institutional, and socio-economic conditions so as to allow a rapid, cost-effective, large scale and sustainable employment of renewable energy in the Mediterranean region;

- Pursue the promotion of renewables among UfM Member States by attaining 20 gigawatts of renewable energy capacity by 2020 on the South and East shore of the Mediterranean;

- Identify and support new RE pilot projects;

- Supply the local market of non-EU UfM parties with most of the electricity produced with the sponsored renewable energy projects, while exporting the rest of such energy to the EU; and

- Create jobs and industrial capacities in Southern and Eastern Mediterranean countries ([90], p. 1).

The potential of the UfM Secretariat's mandate to identify, facilitate, and coordinate renewable energy projects in the Mediterranean region and serve as an institutional forum to attract funding and investments is demonstrated by the Tafila Wind Farm Project (TWFP). The UfM has promoted the TWFP as a leading example of partnership between the public and private sectors that should be replicated by other public and private operators in the region. Indeed, the promoter of the TWFP is a Jordanian-registered company, developed by EP Global Energy of Cyprus (i.e., a privately owned company), that attracted investments from two institutional/public equity holders (i.e., $50 \%$ by a wholly

30 Mauritania has signed the EU Economic Partnership Agreement (EPA) with West Africa, which is not yet in force. See ([87], p. 1). Monaco, through its special relationship with France, is part of the EU customs territory and is located within the external borders of the Schengen area. However, Monaco has not yet signed any PTA with the EU and does not participate in the EU single market. See [88]. 
owned subsidiary of InfraMed Infrastructure ${ }^{31}$ and $31 \%$ by a wholly owned subsidiary of Masdar Corporate $^{32}$ ) and one private equity holder (namely $19 \%$ by EP Energy Projects Holdings LTD, a subsidiary of EP Global Energy) $[95,96]$. Therefore, the UfM may play a key role in providing support for developing renewable energy projects and improving energy security across the Mediterranean region by exploring the feasibility of projects and facilitating their subsequent development, notably through the creation of a platform where private and public operators, investors, and funding could be gathered together to give impulse to renewable energy projects. In particular, the UfM could significantly serve as a hinge to attract the wide availability of capital owned by sovereign wealth funds of the Member States of the Gulf Cooperation Council ${ }^{33}$ so as to back the renewable energy projects to be developed in the Southern and Eastern Mediterranean, where solar power has a great energy potential ([97], pp. 75-79). And emblematically, the TWFP is already showing the interest of the Persian Gulf States, and especially of the United Arab Emirates through the Abu Dhabi Government-owned Masdar Corporate, in investing in green energy initiatives.

\section{Renewable Energy Provisions}

Regarding the EU PTAs with single UfM Member States, it should be pointed out that eight of the 10 agreements under scrutiny (the exceptions being Turkey and Syria) include a renewables-related article, to be found in the provision on cooperation in the energy sector in the following PTAs:

- EU-Algeria Agreement: "the environment, the development of renewable energies and energy efficiency" shall be one of the priority areas of cooperation in the energy and mining sectors ([98], Article 61);

- EU-Egypt Agreement: "the promotion of renewable energies" shall be one of the priority areas of cooperation in energy policy ([99], Article 53);

- EU-Israel Agreement: considering that "global warming and the depletion of fossil fuel sources are a serious threat to mankind", parties "shall therefore cooperate with a view to developing sources of renewable energy, to ensure the use of fuels with the purpose of limiting pollution of the environment and promoting energy conservation" ([100], Article 51(1));

- EU-Jordan Agreement: "the promotion of renewable energies and indigenous energy sources" will be one of the "priority areas" of cooperation in the energy sector ([101], Article 74);

- EU-Lebanon Agreement: cooperation in the energy policy shall focus on the "promotion of renewable energy" ([102], Article 54(a));

31 InfraMed Infrastructure is a long-term investment vehicle launched in 2010 by the following five institutional investors: Cassa Depositi e Prestiti (Italy); Caisse des Dépôts et de Consignations (France); The European Investment Bank; Caisse de Dépôts et de Gestion (Morocco); EFG Hermes (Egypt). InfraMed is the largest investment vehicle dedicated to urban, energy, and transport infrastructure projects in the Mediterranean area, ensuring that all investments are in compliance with high-level environmental protection, social, transparency and procurement standards. See [91].

32 Masdar Corporate is a wholly-owned subsidiary of the Abu Dhabi Government-owned Mubadala Development Company. The Mubadala Development Company is an investment and development company, with a portfolio valued at more than US \$60 billion, established to strengthen Abu Dhabi's growth potential and help the government meet its socioeconomic targets by investing in key social infrastructures. See [92-94].

33 The Gulf Cooperation Council is a political and economic union consisting of the following six Arab states in the Persian Gulf: Bahrain, Kuwait, Oman, Qatar, Saudi Arabia, and the United Arab Emirates. 
- EU-Morocco Agreement: cooperation in the energy sector shall focus on 'renewable energy' ([103], Article 57(a));

- EU-Palestinian Authority Agreement: "the objective of cooperation on energy will be to help the West Bank and Gaza Strip acquire the technologies and infrastructures essential to its development" and one of "the priority areas of cooperation will be" "the promotion of renewable energies" ([104], Article 48); and

- EU-Tunisia Agreement: cooperation in the energy policy "shall focus" on "renewable energy" ([105], Article 57(a)).

Although the above-mentioned provisions encourage cooperation in the energy sector, aimed at boosting renewable energy across the EU and its Mediterranean partners, they seem to be formulated so as to provide only for weak, general, and non-enforceable commitments. In addition, neither the EU PTA with Turkey [106] nor the one with Syria [107] encompasses any provision aimed at fostering and increasing the use of renewable energy, as they do not mention renewables at all.

\subsubsection{EU-Andorra and EU-San Marino PTAs}

The EU has established very similar relations with Andorra, San Marino, and Monaco, as they all are independent small-size and small-population states, having an EU Member State or more as their only neighbors, and financial services and tourism being the basis of their economies. Because of the analogies of their fiscal, monetary and banking systems, the EU has concluded with each of them an agreement on taxation of savings (under which, inter alia, savings income in the form of interest payments earned in such states by residents in EU Member States are subject to a withholding tax whose revenue is mostly transferred to the Member State of residence of the individual concerned) ([108], para. 2.1.2.), and a monetary agreement, enabling them to use the Euro as legal tender and mint Euro coins up to an agreed amount ([108], para. 2.1.1.). Whereas the EU has not yet signed any PTA with Monaco, which, thanks to its special relationship with France, is part of the EU customs territory, EU PTAs with Andorra and San Marino are already in force. However, neither the EU-Andorra PTA [109] nor the EU-San Marino PTA [110], both of which establish a customs union, incorporates any renewable energy-related provisions.

\subsubsection{EU PTAs with non-Neighboring Countries}

After having evaluated all the EU PTAs with neighboring and Mediterranean countries, we will now assess whether the EU PTAs with non-neighboring countries include renewable energy-related provisions. Among the 13 EU PTAs with non-neighboring countries, nine PTAs incorporate renewable energy-related articles and four do not.

The EU PTAs that encompass renewables-related provisions are the following:

- The EU-CARIFORUM States PTA $[111],{ }^{34}$ which contains an article on the cooperation in the eco-innovation and renewable energy sector, where "Parties recognise the importance of fostering

\footnotetext{
34 The EU-CARIFORUM States Economic Partnership Agreement also establishes a free trade area, as it liberalizes trade
} in goods between EU and the following 15 CARIFORUM states: Antigua and Barbuda, Bahamas, Barbados, Belize, 
forms of innovation that benefit the environment in all sectors of their economy", acknowledge that "forms of eco-innovation include [...] renewable sources of energy", and "agree to cooperate" in different areas such as "environmentally-friendly" projects, "projects related to energy efficiency and renewable energy" and the "promotion of eco-innovation networks and clusters, including through public-private partnerships" ([111], Article 138(1)-(2)(a)-(c)).

- The EU-Central America PTA [113], ${ }^{35}$ which comprises three provisions that acknowledge the key role of renewable energy in developing cooperation in environmental policy, the energy sector, and the sustainable development of trade, respectively. Concerning the first provision, "Parties shall promote' a political dialogue on environment and sustainable development that "shall be aimed" at addressing "climate change" in order to boost the "protection of hydro and marine resources, $[\ldots]$ the research and development of alternative fuels and renewable energy technologies" ([113], Article 20). Secondly, a joint objective of the parties "shall be to foster cooperation in the field of energy, in particular sustainable clean and renewable energy sources" and such cooperation "may include", among others, "the promotion of energy saving, energy efficiency, renewable energy and studying of the environmental impact of energy production and consumption" ([113], Article 65(1)-(2)(a),(c)). Finally, since "trade should promote sustainable development", parties "shall endeavour" to "consider those situations in which the elimination or the reduction of obstacles to trade would benefit trade and sustainable development", and facilitate and promote "trade and foreign direct investment in environmental technologies and services, renewable-energy and energy-efficient products and services, including through addressing related non-tariff barriers", and through "the development of practices and programmes aiming at fostering appropriate economic returns from the conservation and sustainable use of the environment" ([113], Article 288).

- The EU-Chile PTA [114], which includes an article regarding cooperation in energy policy, where it is recognized that the aim of such cooperation "shall be to consolidate economic relations in key sectors such as hydroelectricity, oil and gas, renewable energy, energy-saving technology and rural electrification", including through the involvement of public and private operators from both regions in the development of common infrastructure projects ([114], Article 22(1)-(2)(b),(d),(f)).

- The EU-Colombia and Peru PTA [115], which encompasses a provision on climate change that, "considering the global objective of a rapid transition to low-carbon economies," establishes that "Parties agree to consider actions to contribute" to mitigating climate change "through their trade and investment policies", inter alia, by "facilitating the removal of trade and investment barriers to access to, innovation, development, and deployment of goods, services and technologies that can contribute" at addressing climate change and by "promoting measures for $[\ldots]$ renewable energy that respond to environmental and economic needs and minimise technical obstacles to trade" ([115], Article 275(4)-(5)(a)-(b)).

Dominica, Dominican Republic, Grenada, Guyana, Haiti, Jamaica, Saint Kitts and Nevis, Saint Lucia, Saint Vincent and the Grenadines, Suriname, and Trinidad and Tobago. See ([112], pp. 1, 4).

35 The Central America States concerned by this agreement are: Costa Rica, El Salvador, Guatemala, Honduras, Nicaragua, and Panama. 
- The EU-Eastern and Southern Africa (ESA) States PTA [116], ${ }^{36}$ which contains an article on cooperation in the energy sector where, in order to "improve the access of ESA States to modern, efficient, reliable, diversified and sustainable and renewable sources of clean energy at competitive prices" ([116], Article 47(1)), "Parties agree to cooperate" so as to "enhance the production and distribution capacity of existing energy sources, in particular hydro, petroleum and biomass"; "expand and diversify the energy mix to include other potential sources of energy that are socially and environmentally acceptable and that reduce dependency on oil"; and create a market capable of attracting investments, also by encouraging "EU-ESA partnerships, linkages and joint ventures between economic operators" ([116], Article 47(2)).

- The EU-Republic of Korea PTA [118], where, in the provision on trade favouring sustainable development, it is recognized that "Parties shall strive to facilitate and promote trade and foreign direct investment in environmental goods and services, including environmental technologies, sustainable renewable energy, energy efficient products and services and eco-labelled goods, including through addressing related non-tariff barriers" in order to use trade as a vehicle for fostering sustainable development ([118], Article 13.6(2)).

- The EU-Mexico PTA [119], which includes an article on cooperation in the energy sector, setting forth that such cooperation "shall mainly be carried out through [...] joint technological development and infrastructure projects, designing more efficient energy generation processes, promoting the rational use of energy, supporting the use of alternative renewable sources of energy which protect the environment" ([119], Article 23(2)).

- The EU-Overseas Countries and Territories (OCT) PTA [120], ${ }^{37}$ where renewables are considered in three articles concerning, respectively, cooperation in the management of coastal zones, trade fostering sustainable development, and energy. Cooperation in the field of coastal zone management may concern the "conciliation of economic and social activities such as fisheries and aquaculture, tourism, maritime transports [...] with the potential of marine and coastal zones in terms of renewable energy, [...] taking into account impacts of climate change and human activities" ([120], Article 18(b)); cooperation designed to achieve sustainable development in trade "may be pursued", among others, by "facilitating and promoting trade and investment in environmental goods and services" and by "facilitating the removal of obstacles to trade or investment regarding goods and services of particular relevance for climate change mitigation, such as sustainable renewable energy and energy efficient products and services" ([120], Article 58(1)(a)-(b)). Lastly, cooperation in the energy sector "may concern", inter alia, "the development, promotion, use and storage of sustainable energy from renewable energy sources" and the "promotion of energy self-sufficient (renewable energy based) and/or green tourism infrastructures" ([120], Article 23(a)-(f)).

36 The Interim Economic Partnership Agreement with ESA States also establishes a free trade area, as it includes the elimination of imports duties and quotas from ESA States to the EU and a gradual liberalization of EU exports to such countries. The ESA states currently concerned by this Agreement are: Madagascar, Mauritius, Seychelles and Zimbabwe; Comoros and Zambia have not yet signed it. See [117].

37 The 21 OCTs belong constitutionally to Denmark, France, the Netherlands, and the United Kingdom, but they are not part of EU territory, nor are they directly subject to EU law. The first EU PTA with OCTs dates back to 1970 and was established by Council Decision 70/549/EEC. See [121]. 
- The EU-South Africa PTA [122], which envisages two articles favouring an increasing use of renewable energy. The first provision regards cooperation in the energy sector and establishes that such cooperation "shall specifically aim", among other objectives, "to develop new and renewable forms of energy and support infrastructure" ([122], Article 57(2)(e)). The second provision on cooperation concerning environmental protection states that "Parties will cooperate to pursue sustainable development through the rational use of non-renewable natural resources and the sustainable use of renewable natural resources, thus promoting protection of the environment, prevention of its deterioration and the control of pollution" ([122], Article 84(1)).

The articles found in the above-listed nine EU PTAs mostly relate to cooperation in three main areas:

- Environment, climate change, and sustainable development-related policies, where the need to boost renewable energy is stressed, including by facilitating the removal or reduction of barriers to trade and investments in environmental goods, services and technologies, so as to protect the environment, achieve sustainable development and address climate change;

- The energy sector, where it is recognized that cooperation in energy policy should aim at increasing the use of renewables and at developing common renewable energy projects and infrastructures (e.g., through the joint involvement of public and private operators from both Parties) in order to reconcile energy needs with environmental protection and concerns; and

- Trade and sustainable development, where the need to use trade and investments measures to foster sustainable development is acknowledged (e.g., by adopting measures aimed at eliminating or reducing obstacles to trade and investments in environmental goods and services, which include renewable energy products and services).

However, the above-mentioned articles concerning cooperation to be established in environment, energy, trade and sustainable development-related policies seem to provide only for weak, general and non-enforceable commitments.

Lastly, the EU PTAs with Cameroon [123], Côte d'Ivoire [124], Faroe Islands [125], and Papua New Guinea and Fiji [126] do not include any provision aimed at boosting renewable energy, as they do not mention renewables at all.

Table 1 provides a panoramic overview of the EU's PTAs and contracting parties.

Table 1. EU PTAs and contracting parties.

\begin{tabular}{|c|c|c|c|c|c|c|c|}
\hline \multirow{2}{*}{$\begin{array}{l}\text { EU PTAs in Force as } \\
\text { Notified to the WTO }\end{array}$} & \multirow{2}{*}{$\begin{array}{c}\text { Date of } \\
\text { Signature } \\
\end{array}$} & \multicolumn{2}{|c|}{ RE Provision } & \multirow{2}{*}{ WTO MS } & \multirow{2}{*}{$\begin{array}{c}\text { Energy } \\
\text { Charter MS } \\
\end{array}$} & \multirow{2}{*}{ EnC MS } & \multirow{2}{*}{ UfM MS } \\
\hline & & AC & $\mathbf{L E}$ & & & & \\
\hline EU-Albania & $12 / 06 / 2006$ & & & $\mathrm{X}$ & $\mathrm{X}$ & $\mathrm{X}$ & $\mathrm{X}$ \\
\hline EU-Algeria & $22 / 04 / 2002$ & $\mathrm{X}$ & & & & & $\mathrm{X}$ \\
\hline EU-Andorra & 28/06/1991 & & & & & & \\
\hline $\begin{array}{l}\text { EU-Bosnia and } \\
\text { Herzegovina }\end{array}$ & $16 / 06 / 2008$ & & & & $\mathrm{X}$ & $\mathrm{X}$ & $\mathrm{X}$ \\
\hline EU-Cameroon & $15 / 01 / 2009$ & & & $\mathrm{X}$ & & & \\
\hline $\begin{array}{l}\text { EU-CARIFORUM } \\
\text { States }\end{array}$ & $15 / 10 / 2008$ & $\mathrm{X}$ & & $\begin{array}{c}\text { All except Bahamas } \\
\text { and Montserrat }\end{array}$ & & & \\
\hline EU-Central America & $29 / 06 / 2012$ & $\mathrm{X}$ & & $\mathrm{X}$ & & & \\
\hline EU-Chile & $18 / 11 / 2002$ & $\mathrm{X}$ & & $\mathrm{X}$ & & & \\
\hline EU-Colombia and Peru & $26 / 06 / 2012$ & $X$ & & $X$ & & & \\
\hline
\end{tabular}


Table 1. Cont.

\begin{tabular}{|c|c|c|c|c|c|c|c|}
\hline \multirow{2}{*}{$\begin{array}{l}\text { EU PTAs in Force as } \\
\text { Notified to the WTO }\end{array}$} & \multirow{2}{*}{$\begin{array}{c}\text { Date of } \\
\text { Signature }\end{array}$} & \multicolumn{2}{|c|}{ RE Provision } & \multirow{2}{*}{ WTO MS } & \multirow{2}{*}{$\begin{array}{c}\text { Energy } \\
\text { Charter MS }\end{array}$} & \multirow{2}{*}{ EnC MS } & \multirow{2}{*}{ UfM MS } \\
\hline & & $\mathbf{A C}$ & LE & & & & \\
\hline EU-Côte d'Ivoire & $26 / 11 / 2008$ & & & $\mathrm{X}$ & & & \\
\hline $\begin{array}{l}\text { EU-ESA States } \\
\text { Interim EPA }\end{array}$ & 29/08/2009 & $\mathrm{X}$ & & $\mathrm{X}$ & & & \\
\hline EU-Egypt & $25 / 06 / 2001$ & $\mathrm{X}$ & & $\mathrm{x}$ & & & $\mathrm{X}$ \\
\hline EU-Faroe Islands & $06 / 12 / 1996$ & & & & & & \\
\hline EU-Georgia & $27 / 06 / 2014$ & $\mathrm{X}$ & $\mathrm{X}^{* *}$ & $\mathrm{X}$ & $\mathrm{X}$ & Candidate & \\
\hline EU-Iceland & $19 / 12 / 1972$ & & & $\mathrm{X}$ & $*$ & & \\
\hline EU-Israel & $20 / 11 / 1995$ & $\mathrm{X}$ & & $\mathrm{X}$ & & & $\mathrm{X}$ \\
\hline EU-Jordan & $24 / 11 / 1997$ & $\mathrm{X}$ & & $\mathrm{X}$ & & & $\mathrm{X}$ \\
\hline EU-Korea & $06 / 10 / 2010$ & $\mathrm{X}$ & & $\mathrm{X}$ & & & \\
\hline EU-Lebanon & $17 / 06 / 2002$ & $\mathrm{X}$ & & & & & $\mathrm{X}$ \\
\hline EU-Macedonia & 09/04/2001 & & & $\mathrm{X}$ & $\mathrm{X}$ & $\mathrm{X}$ & \\
\hline EU-Mexico & 08/12/1997 & $\mathrm{x}$ & & $\mathrm{x}$ & & & \\
\hline EU-Moldova & $27 / 06 / 2014$ & $\mathrm{X}$ & $\mathrm{X}$ & $\mathrm{X}$ & $\mathrm{X}$ & $\mathrm{X}$ & \\
\hline EU-Montenegro & $15 / 10 / 2007$ & & & $\mathrm{X}$ & & $\mathrm{X}$ & $\mathrm{X}$ \\
\hline EU-Morocco & $26 / 02 / 1996$ & $\mathrm{X}$ & & $\mathrm{X}$ & & & $\mathrm{X}$ \\
\hline EU-Norway & $14 / 05 / 1973$ & & & $\mathrm{x}$ & $*$ & Observer & \\
\hline EU-OCT & 29/09/1970 & $\mathrm{X}$ & & & & & \\
\hline $\begin{array}{l}\text { EU-Palestinian } \\
\text { Authority }\end{array}$ & $24 / 02 / 1997$ & $\mathrm{X}$ & & & & & $\mathrm{X}$ \\
\hline $\begin{array}{l}\text { EU-Papua New } \\
\text { Guinea and Fiji }\end{array}$ & $30 / 07 / 2009$ & & & $\mathrm{X}$ & & & \\
\hline EU-San Marino & $16 / 12 / 1991$ & & & & & & \\
\hline EU-Serbia & $29 / 04 / 2008$ & $\mathrm{X}$ & & & & $\mathrm{X}$ & \\
\hline EU-South Africa & 11/10/1999 & $\mathrm{X}$ & & $\mathrm{X}$ & & & \\
\hline $\begin{array}{l}\text { EU-Switzerland/ } \\
\text { Liechtenstein }\end{array}$ & $22 / 07 / 1972$ & & & $\mathrm{X}$ & $\mathrm{X}$ & & \\
\hline EU-Syria & $18 / 01 / 1977$ & & & & & & $\mathrm{X}$ \\
\hline EU-Tunisia & $17 / 07 / 1995$ & $\mathrm{X}$ & & $\mathrm{X}$ & & & $\mathrm{X}$ \\
\hline EU-Turkey & 06/03/1995 & & & $\mathrm{x}$ & $\mathrm{X}$ & Observer & $\mathrm{X}$ \\
\hline EU-Ukraine & $27 / 06 / 2014$ & $\mathrm{x}$ & & $\mathrm{x}$ & $\mathrm{X}$ & $\mathrm{X}$ & \\
\hline EEA & $02 / 05 / 1992$ & $\begin{array}{l}\text { For all except } \\
\text { Liechtenstein }\end{array}$ & $\begin{array}{l}\text { For all except } \\
\text { Liechtenstein }\end{array}$ & $\mathrm{X}$ & $\begin{array}{l}\text { Only the EU and } \\
\text { Liechtenstein }\end{array}$ & Only the EU & Only the EU \\
\hline
\end{tabular}

Note: $\mathrm{WTO}=$ World Trade Organization; RE = renewable energy; $\mathrm{AC}=$ area covered; LE = legally enforceable; MS = Member State; $\mathrm{EnC}=$ Energy Community; UfM = Union for the Mediterranean; * = states where the ratification of the Energy Charter Treaty is still pending; $* *=$ RE provisions will be enforceable only once Georgia becomes a full-fledged EnC member.

The next section will suggest how the EU could use its network of PTAs to support the renewable energy market across Europe and beyond.

\subsubsection{How to Further Promote Renewable Energy through EU PTAs}

Having analyzed whether the 37 EU PTAs currently in force encompass provisions aimed at promoting renewables, we recommend three tangible ways through which the EU could capitalize its vast network of PTAs to boost the renewable energy market. By providing for new opportunities to support the renewable energy-related market, trade and investments among the parties to EU PTAs, the 
EU may be able to move towards greater energy security and, at the same time, mitigate climate change as renewable energy becomes increasingly exploited and cost-effective. It is thus suggested that the EU could further promote renewables by including provisions in its network of PTAs aimed at:

(1) implementing the acquis on renewables;

(2) protecting investments in the renewable energy sector; and

(3) liberalizing renewable energy goods, services and technologies.

The potential of including such provisions in EU PTAs will be evaluated in relation to both the 37 EU PTAs already in force and the 12 EU PTAs that the EU is currently negotiating or where ratification is still pending at the time of writing [127], which are the following 12 PTAs:

(1) the Comprehensive Economic and Trade Agreement (CETA);

(2) EU-East African Community (EAC) Economic Partnership Agreement (EPA); ${ }^{38}$

(3) EU-India PTA;

(4) EU-Japan PTA;

(5) EU-Malaysia PTA;

(6) EU-Morocco PTA;

(7) EU-Southern African Development Community (SADC) EPA;39

(8) EU-Singapore PTA;

(9) EU-Thailand PTA;

(10) Transatlantic Trade and Investment Partnership (TTIP);

(11)EU-Viet Nam PTA; and

(12)EU-West Africa EPA.

Requiring the Implementation of the Acquis on Renewables

Regarding the acquis on renewables, the following can be said:

- The EU has already incorporated provisions requiring the implementation of the acquis on renewables both in the EEA Agreement and in its PTAs with Moldova and Georgia;

- The EU has, furthermore, provided for the implementation of the renewables acquis within the scope of an international treaty, namely the EnCT;

- The renewables acquis to which all of the above-mentioned instruments refer is currently embodied by the RED;

38 On 16 October 2014, the EU and the EAC Member States (i.e., Burundi, Kenya, Rwanda, Tanzania, and Uganda) have initialled a comprehensive Economic Partnership Agreement, which is not yet in force. The Agreement, inter alia, provides for duty free and quota free access into the EU for all imports from the EAC MSs as well as for a gradual liberalization of the EU imports of goods into the EAC Member States. See ([87], p. 3).

39 On 15 July 2014, the EU has concluded an Economic Partnership Agreement (EPA) with five SADC Member States (i.e., Botswana, Lesotho, Mozambique, Namibia, South Africa and Swaziland), which is currently not yet in force. The EPA guarantees duty free and quota free access to the EU market for the five SADC Member States and a new market access for the EU into Southern African Customs Union. See ([87], p. 3). 
- The scope of application of the RED has been expanded beyond the EU Member States to Iceland, Norway, and the eight EnC Member States (i.e., Albania, Bosnia and Herzegovina, Kosovo, Macedonia, Moldova, Montenegro, Serbia, and Ukraine);

- The common legal framework provided by the RED could be an effective tool to create a well-functioning and competitive renewable energy-related market (for instance, by providing the business community with the necessary long-term stability and legal predictability to make confident and cost-effective investments in the renewable energy sector), thus making renewable energy more economically viable, stimulating research and development on more efficient and competitive RE technologies, and fostering greater energy security in Europe, while also mitigating climate change; and

- By expanding the scope of application of the acquis on renewables, the EU should be able to boost renewable energy and enhance energy security, so as to ensure economic operators more opportunities to make confident and predictable investments in the renewable energy sector.

The EU should renegotiate its PTAs with those neighboring and Mediterranean countries which have not yet implemented or transposed the renewables acquis. Indeed, joint projects and electricity transmission networks could be more easily and cost-effectively developed among the EU Member States and neighboring/Mediterranean states than between EU Member States and non-neighboring countries. Hence, the following is proposed:

- With regard to EFTA Member States, to engage Switzerland in signing the EEA Agreement;

- Concerning the EnC, to make sure that Georgia will become a full-fledged EnC Member State; and

- Regarding the EU's PTAs with individual UfM Member States, to provide for the implementation of the renewables acquis, especially considering the key role that the UfM Secretariat may play in creating an institutional platform where private and public operators, investors, and funding could be gathered together to give impulse to renewable energy projects.

On the other hand, among the 12 PTAs for which an early announcement has been made to the WTO, the Deep and Comprehensive Free Trade Area that the EU is currently negotiating with Morocco in order to extend the scope of their existing PTA is regarded as the most suitable to include a provision requiring the implementation of the renewables acquis. Indeed, among the countries that are negotiating a PTA with the EU, Morocco is the only neighboring/Mediterranean state and, being an UfM Member State, could represent a major partner for EU Member States in the development of renewable energy joint projects and transmission networks.

Protecting Investments in the Renewable Energy Sector

The EU could boost the promotion of renewable energy by including in its vast network of PTAs a provision aimed at protecting the investments in the renewable energy sector. How so? A tangible way to safeguard the renewable energy-related investments through EU PTAs would be the design of an article which provides for the same rules and principles that the Energy Charter Treaty (ECT) envisaged for all the economic activities in the energy sector ([33], Article 1(5)), but only with regard to those activities consisting of the "construction and operation of power generation facilities [...] powered by 
wind and other renewable energy sources" ([128], para. IV(2)(b)(ii); [33], Article 1(5)). In fact, the ECT provides, inter alia, for the following provisions:

(1) protection of foreign investments based on the extension of national treatment or most-favoured-nation treatment (whichever is more favorable) ([33], Article 10(1)-(3));

(2) free trade in energy materials and products based on WTO principles, even extending WTO rules to those CPs that are not yet WTO Member States (e.g., Bosnia and Herzegovina) ([33], Articles 3-4, 29(1)-(2)(a));

(3) freedom of energy transit through pipelines, grids and other means of transportation and "without distinction as to the origin, destination or ownership" of energy materials and products and "without imposing any unreasonable delays, restrictions or charges" ([33], Article 7(1));

(4) protection against key non-commercial risks ([33], Articles 12-13); and

(5) mechanisms for the resolution of investors-to-host state or state-to-state disputes ([33], Articles 26-27).

By including in the EU PTAs an article protecting investments in the economic activities linked to the construction and operation of renewable energy-related power generation facilities, the risks associated with investing in renewables would be either avoided, reduced, or at least regulated under the legal framework provided in the PTAs. Therefore, by guaranteeing investments in the renewable energy sector among its partners, the EU should, in turn, be able to strengthen the renewable energy market and enhance energy security while, at the same time, mitigating climate change by making renewables increasingly exploited and competitive. Among the countries which have already concluded a PTA with the EU, only Albania, Bosnia and Herzegovina, Georgia, Liechtenstein, Macedonia, Moldova, Switzerland, Turkey, and Ukraine have ratified the ECT. ${ }^{40}$ So the EU should renegotiate the PTAs with all the other states, whether neighboring or not, in order to include a provision protecting renewable energy-related investments. Such a provision could be provided in 11 of the 12 EU PTAs, which are not yet in force. In fact, among the countries that are still negotiating a PTA with the EU, Japan is the only state having ratified the ECT.

Indeed, countries which own significant oil, gas, and coal reserves (e.g., Canada, members of the Organization of the Petroleum Exporting Countries, Russia, the US $)^{41}$ could be less reluctant to signing a PTA with the EU that exclusively provides for the protection of investments in the renewable energy sector than to acceding to the ECT, which indiscriminately grants such protection to all the economic activities in the energy sector.

Liberalizing Renewable Energy Goods, Services and Technologies

From the above analysis of EU PTAs, six agreements (i.e., EU PTAs with Central America, Georgia, the Republic of Korea, Moldova, Overseas Countries and Territories, and Ukraine) contain an article on

40 Norway and Iceland are also members of the Energy Charter Conference, but have not yet ratified the ECT. See [129].

41 For instance, at the end of 2013, Canada had a share of $10.3 \%$ of the total oil proved reserves and OPEC countries had $71.9 \%$ of the total oil proved reserves; Russia had a share of $16.8 \%$ of the total natural gas proved reserves and $17.6 \%$ of the total coal proved reserves; and the US had a share of $2.6 \%$ of the total oil proved reserves, $5 \%$ of the total natural gas proved reserves, and $26.6 \%$ of the total coal proved reserves. See ([11], pp. 6, 20, 30). 
trade and sustainable development. In such provision, it is endorsed that Parties should use trade policy as a vehicle for fostering sustainable development. Consequently, there is an acknowledgement of the need to adopt measures aimed at facilitating and supporting trade and foreign direct investments (for instance, by eliminating or reducing obstacles to trade and investments and addressing related non-tariff barriers) in environmental goods, services and technologies, which includes renewable energy goods, services and technologies.

Moreover, in the EU-Colombia and Peru PTA, there is a provision on climate change, resembling the provisions on trade and sustainable development. In fact, the parties are required to consider actions aimed at mitigating climate change through their trade and investment policies, inter alia, by facilitating the removal of barriers to trade and investments in goods, services and technologies that can contribute to addressing climate change, which encompasses renewable energy goods, services and technologies. Therefore, seven of the 37 EU PTAs already in force recognize the need to reconcile trade and environmental policies as well as the enhancement of their mutual support by removing obstacles to trade and investments in renewables-related goods, services and technologies in order to boost sustainable development and mitigate climate change.

The above-mentioned provisions, which do not provide for any legally enforceable obligation, represent a meaningful expression of the WTO negotiations concerning the elimination of obstacles to trade in environmental goods and services. ${ }^{42}$ Indeed, the Fourth WTO Ministerial Conference, held in Doha in 2001, launched multilateral negotiations aimed at "enhancing the mutual supportiveness of trade and environment" ([130], para. 31), through "the reduction or, as appropriate, elimination of tariff and non-tariff barriers to environmental goods and services" ([130], para. 31(iii)). Following the Doha Ministerial Conference, the EU has clarified its approach regarding the identification and definition of environmental goods by submitting an explanatory list of environmental goods [131], which divides environmental goods in the following two categories: "goods used in pollution control and resource management" and "goods that have a high environmental performance or low environmental impacts" ([131], para. 10(a)-(b)). Under the list, the renewable energy-related sector and products (e.g., solar heating, photovoltaic module, wind turbine, small hydro powered generating plant, and plants for producing bio-electricity and bio-heat from waste) can be found among the examples of sub-sectors and products included in the pollution control and resource management category ([131], pp. 7-8).

Given the stalemate of the multilateral trading system since the Doha Conference, in July 2014, 14 WTO Members started plurilateral negotiations for the adoption of an Environmental Goods Agreement (EGA) [132]. The 14 WTO Members include the EU and the following WTO Member States: Australia, Canada, China, Chinese Taipei, Costa Rica, Hong Kong, Japan, New Zealand, Norway, Singapore, the Republic of Korea, Switzerland, and the United States [132]. Such plurilateral negotiations are based on a list of 54 environmental goods set up by the Asia-Pacific Economic Cooperation (APEC) members in 2012. Indeed, APEC members have agreed to pursue a reduction of import tariffs to $5 \%$ or less by the end of 2015 with regard to the 54 listed environmental goods [133]. Hence, the EU actively supports the reduction and/or elimination of barriers to renewable energy-related goods, services and technologies in both its PTAs and within the context of multilateral and plurilateral trade negotiations.

42 The mandate for the WTO negotiations on the elimination of obstacles to trade in environmental goods and services was agreed in the Doha Ministerial Declaration. See ([130], paras. 31-32). 
Therefore, EU PTAs should include a legally enforceable provision aimed at reducing and/or removing tariff and non-tariff barriers to renewable energy goods, services and technologies. Consequently, the EU would need to renegotiate its PTAs already in force and design those currently under negotiation and which still need to be concluded in order to add a legally enforceable provision aimed at removing obstacles to trade in renewable energy goods, services and technologies. The EU would surely enhance the renewables-related market and investments by reducing and/or eliminating barriers to renewable energy goods, services and technologies, since such products, services and technologies would be purchased at lower costs. By liberalizing renewable energy-related trade, the research and developments on more efficient and cost-effective renewable energy technologies will be further stimulated. Making renewable energy goods, services and technologies become increasingly competitive and efficient would certainly help the EU in fostering a growing employment of renewables across Europe, thus enhancing the EU capability to move towards greater energy security, while mitigating climate change at the same time.

From the 37 EU PTAs already in force, the EU-Republic of Korea PTA, the EU-Norway PTA, and the EU-Switzerland/Liechtenstein PTA, together with the EU-Chile PTA, the EU-Mexico PTA, the EU-Papua New Guinea and Fiji PTA, and the EU-Colombia and Peru PTA seem to be better suited to be renegotiated in order to incorporate a legally enforceable provision requiring the reduction and/or removal of barriers to renewable energy goods, services and technologies. In fact, whereas Norway, the Republic of Korea, and Switzerland are three of the 14 WTO Members that have started negotiations for the adoption of an EGA, Chile, Mexico, Papua New Guinea, and Peru are APEC member economies. ${ }^{43}$ Therefore, these countries should be more politically willing and prepared than other EU partners to add in their PTAs with the EU an article aimed at reducing and/or eliminating obstacles to trade in renewable energy goods, services and technologies.

On the other hand, among the 12 PTAs that EU is currently negotiating or where ratification is pending, the CETA, the EU-Japan PTA, the EU-Singapore PTA, and the TTIP, together with the EU-Malaysia PTA, the EU-Thailand PTA, and the EU-Viet Nam PTA seem to be better suited to provide for a legally enforceable provision fostering the reduction and/or the removal of barriers to trade in renewable energy goods, services and technologies. Indeed, whereas Canada, Japan, Singapore, and the US are among the 14 WTO Members that have launched negotiations for the adoption of an EGA, Malaysia, Thailand, and Viet Nam are APEC member economies. ${ }^{44}$ Thus, these countries may also be more politically ready than other EU partners to negotiate a PTA with the EU that includes an article requiring the reduction and/or the removal of tariff and non-tariff obstacles to renewable energy goods, services and technologies.

\section{Conclusions}

43 APEC is composed of the following 21 members: Australia, Brunei Darussalam, Canada, Chile, China, Hong Kong, Indonesia, Japan, Republic of Korea, Malaysia, Mexico, New Zealand, Papua New Guinea, Peru, the Philippines, Russia, Singapore, Chinese Taipei, Thailand, the US, and Viet Nam. See [134]. The Republic of Korea is both among the 14 WTO Members that have initiated negotiations for the adoption of an EGA and an APEC member economy.

44 Canada, Japan, Singapore, and the US are both four of the 14 WTO Members that have started negotiations for the adoption of an EGA and APEC member economies. See [134]. 
In the light of the leading role of renewables within the EU legal and policy framework, this paper has evaluated 37 EU PTAs in force and notified to the WTO in order to assess whether they incorporate provisions aimed at promoting renewables in the EU and its trade partners. From the analysis of the 37 EU PTAs, the following conclusions can be drawn:

- $\quad 15$ EU PTAs do not provide for any renewable energy-related provisions;

- 22 EU PTAs include renewable energy-related provisions, even though only three of them contain legally enforceable obligations (i.e., the EEA Agreement, the EU-Moldova PTA, and the EU-Georgia PTAs), ${ }^{45}$ whereas the remaining 19 EU PTAs provide for general and non-enforceable commitments; and

- The only legally enforceable renewable energy-related provisions found in EU PTAs are those of the RED, as three EU PTAs expressly require Parties to implement the RED (namely the EEA Agreement, the EU-Moldova PTA, and the EU-Georgia PTAs).

Considering these conclusions, three tangible ways through which the EU could capitalize its vast network of PTAs to boost renewable energy have been suggested. The EU PTAs may indeed be used to encourage the renewable energy market and to make the EU increasingly energy secure by including provisions, inter alia, aimed at:

(1) implementing the acquis on renewables;

(2) protecting investments in the renewable energy sector; and

(3) liberalizing renewable energy goods, services and technologies.

Using PTAs to foster the growth of the renewable energy market, trade and investments among the EU and its trade partners would place the EU in a better position to move towards greater energy security and, at the same time, mitigate climate change, as renewable energy becomes further exploited, developed and economically viable. Moreover, due not only to the increasing number of PTAs but also the opportunities they present, the EU ought to be able to successfully facilitate renewable energy to exist and be placed within such agreements. For instance, the EU could make sure that any of the negative effects associated with PTAs is minimized when introducing renewables in PTAs. In doing so, it will safeguard renewables in instances where they could otherwise be compromised in a PTA if the necessary precautions are not taken.

Another factor is the need to overcome the way in which renewables are viewed in that they are difficult and expensive to produce, attain and transport. Through significant research and many trials, the production of renewable energy will become more and more commonplace. A good analogy is that of computers or cell phones, which initially used to be (very) expensive and today are accessible to almost anyone in the world. This new reality will only become easier as technologies develop, allowing for even greater production as well as ease of transferring the energy. There are already a number of substantial projects underway that are using a variety of natural and sustainable ways to create renewable energy, which are showing very promising results.

Moving towards a more sustainable, environmentally friendly and green economy is essential to protect Earth from further degradation and climate change. This can only be accomplished through the

45 Regarding Georgia, it will be required to transpose and implement the provisions of the RED only once it becomes a full-fledged member of the Energy Community. 
use of renewables and can only happen once governments are able to move away from conventional energy sources. These resources include the use of fossil fuels, which are now easily attainable; however, reserves are being depleted and finite. This is why it is imperative that a move towards an overall greener economy be made, one that incorporates renewable energies so that they may diminish and, perhaps one day, render other sources that cause environmental degradation impractical, leading "conventional energy' to become a source of energy of the past. To reach this point, countries need to understand that investing money in renewable energy projects today will only benefit them in the future, irrespective of how implausible it may seem.

PTAs are, therefore, a great way to promote and integrate renewable energy in the economy. By introducing renewables chapters in such agreements, it is anticipated that it will aid in the development of renewable energy to eventually become the "norm" and provide an easier and more efficient way to introduce renewables in the EU marketplace. It is likely that PTAs will be efficacious in doing so; however, uncertainty does remain. This ambiguity will persist until renewable energies do become more established as a source of providing energy and are integrated in the EU (and elsewhere).

\section{Author Contributions}

All three authors have contributed as a team from the inception of the paper. Its various parts have been written by all three authors in a collaborative manner.

\section{Conflicts of Interest}

The authors declare no conflict of interest.

\section{References and Notes}

1. Jeremy Bender, and Reuters. "Putin: Europe Can't Stop Buying Russian Gas." Business Insider, 24 October 2014. Available online: http:/www.businessinsider.com/putin-europe-cant-stopbuying-russian-gas-2014-10? IR=T (accessed on 27 July 2015).

2. European Commission. "Overview of the secondary EU legislation that falls under the legislative competence of DG ENER and that is currently in force." 19 December 2014. Available online: https://ec.europa.eu/energy/sites/ener/files/documents/2014-12-19-ener-legislation.pdf (accessed on 27 July 2015).

3. European Commission. "Energy Security Strategy." Available online: https:/ec.europa.eu/ energy/en/topics/energy-strategy/energy-security-strategy (accessed on 27 July 2015).

4. Decision 406/2009/EC of 23 April 2009 on the effort of Member States to reduce their greenhouse gas emissions to meet the Community's greenhouse gas emission reduction commitments up to 2020 [2009] OJ L140/136.

5. Communication from the Commission to the European Parliament, the Council, the European Economic and Social Committee and the Committee of the Regions. "A Policy Framework for Climate and Energy in the Period from 2020 to 2030.” Available online: http://eur-lex.europa.eu/legalcontent/EN/TXT/PDF/?uri=CELEX:52014DC0015\&from=EN (accessed on 27 July 2015).

6. Communication from the Commission to the European Parliament, the Council, the European Economic and Social Committee and the Committee of the Regions. "A Roadmap for Moving to 
a Competitive Low Carbon Economy in 2050." Available online: http://eur-lex.europa.eu/ resource.html?uri=cellar:5db26ecc-ba4e-4de2-ae08-dba649109d18.0002.03/DOC_1\&format=PDF (accessed on 27 July 2015).

7. Directive 2009/28/EC of 23 April 2009 on the promotion of the use of energy from renewable sources and amending and subsequently repealing Directives 2001/77/EC and 2003/30/EC (Renewables Directive) [2009] OJ L140/16.

8. Communication from the Commission to the European Parliament and the Council. "European Energy Security Strategy.” Available online: http://eur-lex.europa.eu/legal-content/EN/TXT/ PDF/?uri=CELEX:52014DC0330\&from=EN (accessed on 27 July 2015).

9. European Commission. "EU Energy in Figures - Statistical Pocketbook 2014." Available online: https://ec.europa.eu/energy/sites/ener/files/documents/2014_pocketbook.pdf (accessed on 27 July 2015).

10. Eurostat. "Primary production of renewable energy by type." Available online: http://epp.eurostat.ec.europa.eu/tgm/table.do?tab=table\&init=1\&plugin=1\&language=en\&pcode $=$ ten00081 (accessed on 27 July 2015).

11. BP. "Statistical Review of World Energy." June 2014. Available online: http://www.bp.com/ content/dam/bp/pdf/Energy-economics/statistical-review-2014/BP-statistical-review-of-worldenergy-2014-full-report.pdf (accessed on 27 July 2015).

12. International Renewable Energy Agency. "Renewable Power Generation Costs in 2012: An Overview." January 2013. Available online: http://www.irena.org/menu/index.aspx?mnu= Subcat\&PriMenuID=36\&CatID=141\&SubcatID=277 (accessed on 27 July 2015).

13. Rosemary Lyster. "Renewable Energy in the Context of Climate Change and Global Energy Resources." In Law as Change: Engaging with the Life and Scholarship of Adrian Bradbrook. Adelaide: University of Adelaide Press, 2014.

14. International Energy Agency. "World Energy Outlook 2014 - Executive Summary." November 2014. Available online: http://www.iea.org/publications/freepublications/publication/worldenergy-outlook-2014---executive-summary.html (accessed on 27 July 2015).

15. Pilita Clark. "Renewable power will overtake coal if climate pledges are kept." Financial Times, 15 June 2015. Available online: http://www.ft.com/cms/s/0/43c8d800-1119-11e5-a8b1-00144 feabdc0.html\#axzz3h7GMX3he (accessed on 27 July 2015).

16. International Energy Agency. "Energy and Climate Change. World Energy Outlook Special Report." 2015. Available online: https://www.iea.org/publications/freepublications/publication/ WEO2015SpecialReportonEnergyandClimateChange.pdf (accessed on 27 July 2015).

17. Volker Oschmann. "Introduction to European Law on Renewable Energy Sources." In From Debate to Design: Issues in Clean Energy and Climate Change Law and Policy-A Report on the work of the REIL Network 2007-2008. Edited by Leslie Parker, Jennifer Ronk, Rachel Maxwell, REIL Network, Bradford Gentry, Yale School of Forestry \& Environmental Studies, Martijn Wilder, Baker \& McKenzie, James Cameron and Climate Change Capital. New Haven: Yale School of Forestry \& Environmental Studies, 2008, pp. 19-29.

18. Directive 2001/77/EC of 27 September 2001 on the promotion of electricity produced from renewable energy sources in the internal electricity market [2001] OJ L283/33. 
19. Directive $98 / 70 / \mathrm{EC}$ of 13 October 1998 relating to the quality of petrol and diesel fuels and amending Council Directive 93/12/EEC [1998] OJ L350/58.

20. Maria Lee. EU Environmental Law, Governance and Decision-Making, 2nd ed. Oxford: Hart Publishing, 2014, p. 147.

21. Case C-129/96 Inter-Environment Wallonie v Régione Wallone [1997] ECR I-7411.

22. Manuel A. J. Teehankee, Ingrid Jegou, and Rafael Jacques Rodrigues. Multilateral Negotiations at the Intersection of Trade and Climate Change: An Overview of Developing Countries'Priorities in UNCSD, UNFCCC and WTO Processes. Geneva: ICTSD Program on Global Economic Policy and Institutions, 2012.

23. United Nations. "What is 'Rio+20'?” Available online: http://www.un.org/en/sustainablefuture/ about.shtml (accessed on 27 July 2015).

24. Eurostat. "Share of Renewable Energy in Gross Final Energy Consumption." Available online: http://ec.europa.eu/eurostat/tgm/table.do?tab=table\&init=1\&language=en\&pcode=t2020_31\&plu gin=1 (accessed on 27 July 2015).

25. European Commission. "Summary of the Member States Forecast Documents." Available online: https://ec.europa.eu/energy/sites/ener/files/dir_2009_0028_article_4_3_forecast_by_ms_symmary. pdf (accessed on 27 July 2015).

26. Eurostat. "Energy Saving-Annual Data." Available online: http://appsso.eurostat.ec.europa.eu/ nui/show.do?dataset=nrg_ind_334a\&lang=en (accessed on 27 July 2015).

27. European Commission. "Guidance on the Use of Renewable Energy Cooperation Mechanism." Available online: https://ec.europa.eu/energy/sites/ener/files/documents/com_2013_public_ intervention_swd05_en.pdf (accessed on 27 July 2015).

28. Eurostat. "Renewable Energy Statistics." Available online: http://ec.europa.eu/eurostat/statisticsexplained/index.php/Renewable_energy_statistics (accessed on 27 July 2015).

29. Report from the Commission to the European Parliament, the Council, the European Economic and Social Committee and the Committee of the Regions. "Renewable Energy Progress Report. $\operatorname{COM(2013)} 175$ final.” Available online: http://eur-lex.europa.eu/legal-content/EN/TXT/PDF/ ?uri=CELEX:52013DC0175\&from=EN (accessed on 27 July 2015).

30. European Council Conclusions (23 and 24 October 2014) EUCO 169/14.

31. European Commission. "2030 Framework for Climate and Energy_Outcome of the October 2014 European Council.” Available online: http://ec.europa.eu/clima/policies/2030/docs/2030_euco_ conclusions_en.pdf (accessed on 27 July 2015).

32. Author or organizer. "Industry Call for Binding Renewable Energy Target in 2030 Package." 17 September 2013. Available online: http:/www.alstom.com/Global/Group/Resources/Documents/ News\%20and\%20Events/Open_Letter_Industry_Call_for_2030_RES_Target_September_2013.pdf (accessed on 27 July 2015).

33. Energy Charter Treaty, 2080 UNTS 95; 34 ILM 360 (1995).

34. Kim Talus. EU Energy Law and Policy: A Critical Account. Oxford: Oxford University Press, 2013.

35. Craig Bamberger, and Thomas Wälde. "The Energy Charter Treaty.” In Energy Law in Europe, 2nd ed. Edited by Martha Roggenkamp, Catherine Redgwell, Anita Rønne and Iñigo del Guayo. Oxford: Oxford University Press, 2008. 
36. Rafael Leal-Arcas, and Andrew Filis. "The Energy Community and the Energy Charter Treaty: Special Legal Regimes, their Systemic Relationship to the EU, and their Dispute Settlement Arrangements." Oil, Gas \& Energy Law Journal 12 (2014): 1-42.

37. General Agreement on Tariffs and Trade (GATT) 1867 UNTS 187; 33 ILM 1153 (1994).

38. European Commission. "A European Strategy for Sustainable, Competitive and Secure Energy. $\operatorname{COM(2006)} 105$ final.” Available online: http://eur-lex.europa.eu/legal-content/EN/TXT/PDF/ ?uri=CELEX:52006DC0105\&from=EN (accessed on 27 July 2015).

39. Volker Oschmann. "Renewable Energy Sources in European Law: An Overview." Journal for European Environmental \& Planning Law 3 (2006): 478-85.

40. Decision on Differential and More Favourable Treatment, Reciprocity, and Fuller Participation of Developing Countries. GATT Document L/4903, 28 November 1979 (Enabling Clause).

41. Jagdish Bhagwati. Termites in the Trading System: How Preferential Agreements Undermine Free Trade. Oxford: Oxford University Press, 2008.

42. Rafael Leal-Arcas. "Climate Change Mitigation from the Bottom Up: Using Preferential Trade Agreements to Promote Climate Change Mitigation" Carbon and Climate Law Review 7 (2013): 34-42.

43. World Trade Organization. "List of all RTAs." Available online: http://rtais.wto.org/UI/ PublicAllRTAList.aspx (accessed on 27 July 2015).

44. Petros C. Mavroidis. "Doha, Dohalf or Dohaha? The WTO Licks its Wounds" Trade, Law and Development 3 (2011): 367-81.

45. United Nations Framework Convention on Climate Change. "Status of the Doha Amendment." Available online: http://unfccc.int/kyoto_protocol/doha_amendment/items/7362.php (accessed on 27 July 2015).

46. DG Trade. "Trade Negotiations Step by Step." September 2013. Available online: http://trade.ec.europa.eu/doclib/docs/2012/june/tradoc_149616.pdf (accessed on 27 July 2015).

47. General Agreement on Trade in Services (GATS) 1869 UNTS 183; 33 ILM 1167 (1994).

48. Warren H. Maruyama. "Preferential Trade Arrangements and the Erosion of the WTO's MFN Principle.” Stanford Journal of International Law 46 (2010): 177-96.

49. Rafael Leal-Arcas. "Proliferation of Regional Trade Agreements: Complementing or Supplanting Multilateralism?” Chicago Journal of International Law 11 (2011): 597-629.

50. Henrik Horn, Petros C. Mavroidis, and André Sapir. "EU and U.S. Preferential Trade Agreements: Deepening or Widening of WTO Commitments." In Preferential Trade Agreements: A Law and Economics Analysis. Edited by Kyle W. Bagwell and Petros C. Mavroidis. Cambridge: Cambridge University Press, 2011, pp. 150-72.

51. WTO. "Regional Trade Agreements." Available online: http://www.wto.org/english/tratop_e/ region_e/region_e.htm (accessed on 27 July 2015).

52. Raymond J. Ahearn. "Europe's Preferential Trade Agreements: Status, Content, and Implications." Congressional Research Service, 3 March 2011. Available online: http://fas.org/sgp/crs/row/ R41143.pdf (accessed on 27 July 2015).

53. European External Action Service. "EU Relations with European Economic Area (EEA)." Available online: http://eeas.europa.eu/eea/ (accessed on 27 July 2015).

54. Agreement on the European Economic Area [1994] OJ L1/3. 
55. Treaty on the Functioning of the European Union (TFEU) [2012] OJ C326/47.

56. European Economic Area. "EEA Agreement-Annex IV-Energy." Available online: http://www.efta.int/media/documents/legal-texts/eea/the-eea-agreement/Annexes $\% 20$ to\%20the \%20Agreement/annex4.pdf (accessed on 27 July 2015).

57. Eurostat. "Share of Energy from Renewable Sources." Available online: http://appsso.eurostat.ec.europa.eu/nui/show.do?dataset=nrg_ind_335a\&lang=en (accessed on 27 July 2015).

58. Agreement between the EFTA States on the Establishment of a Surveillance Authority and a Court of Justice [1994] OJ L344/1.

59. Agreement between the European Economic Community and the Republic of Iceland [1972] OJ L301/4.

60. Agreement between the European Economic Community and the Kingdom of Norway [1973] OJ L171/2.

61. Agreement between the European Economic Community and the Swiss Confederation [1973] OJ L300/191.

62. Additional Agreement on Validity for the Principality of Liechtenstein of the Agreement between the European Economic Community and the Swiss Confederation of 22 July 1972 [1972] OJ L300/281.

63. Swiss Federal Office of Energy. "Energy Negotiations between Switzerland and the EU." Available online: http://www.bfe.admin.ch/themen/00612/00618/index.html?lang=en (accessed on 29 July 2015).

64. Treaty establishing the Energy Community [2006] OJ L198/18.

65. Energy Community. "Members." Available online: https://www.energy-community.org/portal/ page/portal/ENC_HOME/MEMBERS (accessed on 29 July 2015).

66. Accordance with International Law of the Unilateral Declaration of Independence in Respect of Kosovo, Advisory Opinion, I.C.J. Reports 2010, p. 403.

67. Council Decision 2006/500/EC on the conclusion by the European Community of the Energy Community Treaty [2006] OJ L198/15.

68. Directive 2003/54/EC of 26 June 2003 concerning common rules for the internal market in electricity, [2003] OJ L176/37.

69. Directive $2003 / 55 /$ EC of 26 June 2003 concerning common rules for the internal market in natural gas [2003] OJ L176/57.

70. Energy Community. "Energy Community Acquis." Available online: https://www.energycommunity.org/portal/page/portal/ENC_HOME/ENERGY_COMMUNITY/Legal/EU_Legislation (accessed on 29 July 2015).

71. "Report from the Commission to the European Parliament and the Council under Article 7 of Decision 2006/500/EC [2011] COM(2011) 105 final.” Available online: http://eur-lex.europa.eu/ legal-content/EN/TXT/PDF/?uri=CELEX:52011DC0105\&from=EN (accessed on 29 July 2015).

72. Ministerial Council Decision 2012/04/MC-EnC of 18 October 2012 on the implementation of Directive 2009/28/EC and amending Article 20 of the Energy Community Treaty [2012].

73. Energy Community Secretariat. “Annual Implementation Report 2013/2014”. Energy Community, 1 August 2014. Available online: http://www.energy-community.org/portal/page/portal/ENC_ 
HOME/DOCS/3356393/Energy_Community_Implementation_Report_2014_WEB.pdf (accessed on 29 July 2015).

74. Ministerial Council Procedural Act 2008/01/MG-EnC of 27 June 2008 on the Rules of Procedure for Dispute Settlement under the Treaty.

75. Council of the European Union, Stabilisation and Association Agreement between the European Communities and their Member States, of the one part, and the Republic of Albania, of the other part [2006] 8164/06 COWEB 76.

76. Interim Agreement on trade and trade-related matters between the European Community, of the one part, and Bosnia and Herzegovina, of the other part [2008] OJ L169/13.

77. Interim Agreement on trade and trade-related matters between the European Community, of the one part, and the former Yugoslav Republic of Macedonia, of the other part [2001] OJ L124/2.

78. Interim Agreement on trade and trade-related matters between the European Community, of the one part, and the Republic of Montenegro, of the other part [2007] OJ L345/2.

79. Association Agreement between the European Union and the European Atomic Energy Community and their Member States, of the one part, and the Republic of Moldova, of the other part [2014] OJ L260/4.

80. Stabilisation and Association Agreement between the European Communities and their Member States, of the one part, and the Republic of Serbia, of the other part [2013] OJ L278/16.

81. Association Agreement between the European Union and its Member States, of the one part, and Ukraine, of the other part [2014] OJ L161/3.

82. Association Agreement between the European Union and the European Atomic Energy Community and their Member States, of the one part, and Georgia, of the other part [2014] OJ L261/4.

83. European Commission. "Commission launches negotiations with Georgia to join the Energy Community." European Commission Press Release, 20 February 2014. Available online: http://europa.eu/rapid/press-release_IP-14-170_en.htm (accessed on 29 July 2015).

84. Rafael Leal-Arcas. Theory and Practice of EC External Trade Law and Policy. London: Cameron May, 2008, p. 282.

85. European External Action Service. "The EU's Relations with Syria." Available online: http://www.eeas.europa.eu/syria/index_en.htm (accessed on 29 July 2015).

86. Union for the Mediterranean Secretariat. "Joint Declaration of the Paris Summit for the Mediterranean.” 13 July 2008. Available online: http://ufmsecretariat.org/wp-content/uploads/ 2012/09/ufm_paris_declaration1.pdf (accessed on 29 July 2015).

87. European Commission. "Overview of EPA Negotiations." May 2015. Available online: http://trade.ec.europa.eu/doclib/docs/2009/september/tradoc_144912.pdf (accessed on 29 July 2015).

88. European External Action Service. "EU Relations with Principality of Monaco.” Available online: http://www.eeas.europa.eu/monaco/index_en.htm (accessed on 29 July 2015).

89. Union for the Mediterranean. "Statutes of the Secretariat of the Union for the Mediterranean." Available online: http://ufmsecretariat.org/wp-content/uploads/2012/09/Statutes-UfMS.pdf (accessed on 29 July 2015). 
90. Union for the Mediterranean. "Mediterranean Solar Plan (MSP)." Available online: http://ufmsecretariat.org/wp-content/uploads/2014/01/MEDITERRANEAN-SOLAR-PLANMSP.pdf (accessed on 29 July 2015).

91. InfraMed. "Genesis.” Available online: http://inframed.com/genesis/ (accessed on 29 July 2015).

92. Masdar Corporate. “About Masdar.” Available online: http://www.masdar.ae/en/masdar/our-story (accessed on 29 July 2015).

93. Mubadala Development Company. "Organization Structure." Available online: http://www.mubadala.com/en/who-we-are/organization-structure (accessed on 29 July 2015).

94. Mubadala Development Company. "Who We Are-Overview." Available online: http://www.mubadala.com/en/who-we-are/overview (accessed on 29 July 2015).

95. Union for the Mediterranean. “Tafila Wind Farm.” Available online: http://ufmsecretariat.org/ tafila-wind-farms/ (accessed on 29 July 2015).

96. Union for the Mediterranean. "Tafila Wind Farm-Project Snapshot." Available online: http://ufmsecretariat.org/wp-content/uploads/2014/09/TAFILA-WIND-FARM.pdf (accessed on 29 July 2015).

97. Simone Tagliapietra. "The Geoeconomics of Sovereign Wealth Funds and Renewable Energy: Towards a New Energy Paradigm in the Euro-Mediterranean Region.” European Energy Journal 3 (2013): 75-79.

98. Euro-Mediterranean Agreement establishing an Association between the European Community and its Member States, of the one part, and the People's Democratic Republic of Algeria, of the other part [2005] OJ L265/2.

99. Euro-Mediterranean Agreement establishing an Association between the European Communities and their Member States, of the one part, and the Arab Republic of Egypt, of the other part [2004] OJ L304/39.

100. Euro-Mediterranean Agreement establishing an association between the European Communities and their Member States, of the one part, and the State of Israel, of the other part [2000] OJ L147/3.

101. Euro-Mediterranean Agreement establishing an Association between the European Communities and their Member States, of the one part, and the Hashemite Kingdom of Jordan, of the other part [2002] OJ L129/3.

102. Euro-Mediterranean Agreement establishing an Association between the European Community and its Member States, of the one part, and the Republic of Lebanon, of the other part [2006] OJ L143/2.

103. Euro-Mediterranean Agreement establishing an association between the European Communities and their Member States, of the one part, and the Kingdom of Morocco, of the other part [2000] OJ L70/2.

104. Euro-Mediterranean Interim Association Agreement on trade and cooperation between the European Community, of the one part, and the Palestine Liberation Organization (PLO) for the benefit of the Palestinian Authority of the West Bank and the Gaza Strip, of the other part [1997] OJ L187/3.

105. Euro-Mediterranean Agreement establishing an association between the European Communities and their Member States, of the one part, and the Republic of Tunisia, of the other part [1998] OJ L97/2. 
106. Decision No 1/95 of the EC-Turkey Association Council of 22 December 1995 on implementing the final phase of the Customs Union [1996] OJ L35/1.

107. Cooperation Agreement between the European Economic Community and the Syrian Arab Republic [1978] OJ L 269/2.

108. European Commission. "EU Relations with the Principality of Andorra, the Principality of Monaco and the Republic of San Marino. COM(2012) 680 final." Available online: http://eur-lex.europa.eu/ resource.html?uri=cellar:e87ecb26-d927-4613-9be4-961c8a43735b.0001.03/DOC_1\&format=PDF (accessed on 29 July 2015).

109. Agreement between the European Economic Community and the Principality of Andorra [1990] OJ L374/16.

110. Agreement on Cooperation and Customs Union between the European Economic Community and the Republic of San Marino [2002] OJ L84/43.

111. Economic Partnership Agreement between the CARIFORUM States, of the one part, and the European Community and its Member States, of the other part [2008] OJ L 289/I/3.

112. European Commission-Trade. "Introduction to the CARIFORUM-EC EPA." October 2008. Available online: http://eeas.europa.eu/delegations/barbados/documents/eu_barbados/epa_ introduction_en.pdf (accessed on 29 July 2015).

113. Agreement establishing an Association between the European Union and its Member States, on the one hand, and Central America on the other [2012] OJ L346/3.

114. Agreement establishing an association between the European Community and its Member States, of the one part, and the Republic of Chile, of the other part [2002] OJ L 352/3.

115. Trade Agreement between the European Union and its Member States, of the one part, and Colombia and Peru, of the other part [2012] OJ L354/3.

116. Interim Agreement establishing a framework for an Economic Partnership Agreement between the Eastern and Southern Africa States, on the one part, and the European Community and its Member States, on the other part [2012] OJ L111/2.

117. European Commission-Trade. "Eastern and Southern Africa (ESA)." Available online: http://ec.europa.eu/trade/policy/countries-and-regions/regions/esa/ (accessed on 29 July 2015).

118. Free Trade Agreement between the European Union and its Member States, of the one part, and the Republic of Korea, of the other part [2011] OJ L127/6.

119. Economic Partnership, Political Coordination and Cooperation Agreement between the European Community and its Member States, of the one part, and the United Mexican States, of the other part [2000] OJ L276/45.

120. Council Decision 2013/755/EU on the Association of the Overseas Countries and Territories with the European Union [2013] OJ L344/1.

121. Council Decision 70/549/EEC on the Association of the Overseas Countries and Territories with the European Economic Community [1970] OJ L282/83.

122. Agreement on Trade, Development and Cooperation between the European Community and its Member States, of the one part, and the Republic of South Africa, of the other part [1999] OJ L311/3. 
123. Interim Agreement with a view to an Economic Partnership Agreement between the European Community and its Member States, of the one part, and the Central Africa Party, of the other part [2009] OJ L57/2.

124. Stepping Stone Economic Partnership Agreement between Côte d'Ivoire, of the one part, and the European Community and its Member States, of the other part [2009] OJ L59/3.

125. Agreement between the European Community, of the one part, and the Government of Denmark and the Home Government of the Faroe Islands, of the other part [1997] OJ L53/2.

126. Interim Partnership Agreement between the European Community, of the one part, and the Pacific States, of the other part [2009] OJ L272.

127. World Trade Organization. "List of All Early Announcements Made to WTO." Available online: http://rtais.wto.org/UI/PublicEARTAList.aspx (accessed on 29 July 2015).

128. Energy Charter Secretariat. "Final Act of the European Energy Charter ConferenceUnderstandings." In The Energy Charter Treaty and Related Documents-A Legal Framework for International Energy Cooperation. Brussels: Energy Charter Secretariat, 2004, pp. 25-30. Available online: http://www.encharter.org/fileadmin/user_upload/document/EN.pdf (accessed on 29 July 2015).

129. Energy Charter. "Members and Observers." Available online: http://www.encharter.org/ index.php?id=61\&L=0L\%200\%203\%200\%204id (accessed on 29 July 2015).

130. World Trade Organization. "Ministerial Declaration." 14 November 2001. Available online: http://www.wto.org/english/thewto_e/minist_e/min01_e/mindecl_e.pdf (accessed on 29 July 2015).

131. World Trade Organization. "Market Access for Environmental Goods." 17 February 2005. Available online: http://rade.ec.europa.eu/doclib/docs/2005/march/tradoc_121614.pdf (accessed on 29 July 2015).

132. World Trade Organization. "Azevêdo Welcomes Launch of Plurilateral Environmental Goods Negotiations.” 8 July 2014. Available online: http://www.wto.org/english/news_e/news14_e/ envir_08jul14_e.htm (accessed on 29 July 2015).

133. Asia-Pacific Economic Cooperation (APEC). "20th APEC Economic Leaders' DeclarationAnnex C-APEC List of Environmental Goods.” 2012. Available online: http://www.apec.org/ /media/Files/LeadersDeclarations/2012/2012_AELM_Declaration_AnnexC.pdf (accessed on 29 July 2015).

134. Asia-Pacific Economic Cooperation (APEC). "Member Economies." Available online:

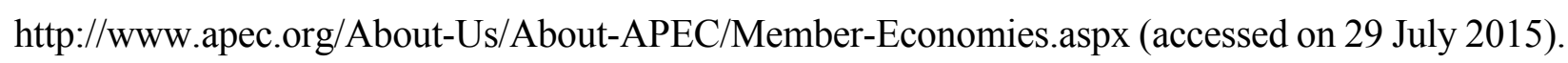

(C) 2015 by the authors; licensee MDPI, Basel, Switzerland. This article is an open access article distributed under the terms and conditions of the Creative Commons Attribution license (http://creativecommons.org/licenses/by/4.0/). 